UNIVERSIDADE DE SÃO PAULO

FACULDADE DE ODONTOLOGIA DE BAURU

Fernanda Menechino Costa

Oficinas de Aprimoramento da Comunicação para Inclusão dos Jovens no Mercado de Trabalho 
FERNANDA MENECHINO COSTA

Oficinas de Aprimoramento da Comunicação para Inclusão dos Jovens no Mercado de Trabalho

Dissertação apresentada à Faculdade de Odontologia de Bauru da Universidade de São Paulo para obtenção do título de mestre em Odontologia.

Área de concentração: Odontologia em Saúde Coletiva.

Orientador: Prof. Dr. José Roberto de Pereira Lauris

\section{Bauru}


Costa, Fernanda Menechino

C823o Oficinas de Aprimoramento da Comunicação para Inclusão dos Jovens no Mercado de Trabalho / Fernanda Menechino Costa. Bauru, 2008. 149p.: il.; 30cm

Dissertação (Mestrado) -- Faculdade de Odontologia de BauruUniversidade de São Paulo.

Orientador: Prof. Dr. José Roberto Pereira Lauris

Autorizo, exclusivamente para fins acadêmico e científicos, a reprodução total ou parcial desta dissertação, por processos fotocopiadores e outros meios eletrônicos.

Assinatura:

Data:

Comitê de Ética da FOB-USP

Protocolo número: 91/2007

Data: $27 / 06 / 2007$ 


\section{FERNANDA MENECHINO COSTA}

\section{Dados Curriculares}

31 de agosto de 1982

Mococa-SP

Filiação

2001-2005

2004-2005

2007-2008

Associações:

\author{
Nascimento
}

Joel Geraldo da Costa

Marinês Siqueira Menechino Costa

Curso de Graduação em Fonoaudiologia pela Universidade de Ribeirão Preto-UNAERP.

Aperfeiçoamento em Saúde Coletiva, pela Universidade de Ribeirão Preto-UNAERP.

Curso de Pós-Graduação em Odontologia em Saúde Coletiva, nível Mestrado. Faculdade de Odontologia de Bauru- Universidade de São Paulo.

-Sociedade Brasileira de Fonoaudiologia - SBFa.

- CRFa - São Paulo - Conselho Regional de Fonoaudiologia. 


\section{DEDICATÓRIA}

Dedico este trabalho a todas as pessoas que direta e indiretamente caminharam ao meu lado nesses anos de trabalho, me ajudando no possível para que este trabalho fosse concluído.

Aos meus pais Joel e Marinês, pelo amor incondicional!!!

A minha irmã Marina e meu cunhado Ricardo pelo amor, dedicação, e confiança que sempre tiveram em todos os momentos da minha vida.

Aos meus avós paterno Geraldo (não mais aqui presente) e Aparecida.

Aos meus avós materno Vitor (não mais aqui presente) e Wanda.

A todos da família Menechino e da família Costa que me apoiaram quando decidi cursar o mestrado.

A todos meus amigos que direta ou indiretamente me ajudaram para que este trabalho fosse concluído.

Dedico este trabalho à todos vocês! 


\section{AGRADECIMENTO}

A Deus que permitiu que este trabalho fosse concluído;

Aos meus pais por me oferecer a oportunidade de cursar uma Pós-Graduação.

À minha irmã Marina por ter me ajudado e dado conselhos durante os momentos em que pensei em desistir de tudo por não acreditar em mim.

Às minhas amigas Flávia, Cíntia e Jaqueline, pela eterna amizade existente entre nós.

À minha Psicóloga e amiga Vera Lima pelo apoio durante toda minha vida em Bauru.

Ao meu Orientador Prof. Dr José Roberto Pereira Lauris, pelo acompanhamento, orientação, confiança e pelas palavras de carinho e incentivo a mim dedicado.

A Profa Dra Magali de Lourdes Caldana, pela atenção, confiança e os ensinamentos desde o curso de Graduação em Ribeirão Preto-SP.

\section{A Profa Dra Patrícia Pupim Mandrá e a Profa Dra Patrícia de Abreu Pinheiro Crenitte por me ajudar na elaboração deste trabalho.}

Aos meus amigos de mestrado Roberta, Leslie, Juliane, Elen, Gabriel, Fabiano, Maurício, César e Agnes, agradeço o carinho e coleguismo dispensados por vocês. 
A toda a minha família por sempre acreditar em mim e pela força oferecida durante esses

anos.

Aos Professores e funcionários do Departamento Odontopediatria, Ortodontia em Saúde

Coletiva, pela amizade e convivência agradável e construtiva.

Ao Prof. Dr. José Roberto de Magalhães Bastos pelo apoio quando decidi encarar a prova de Mestrado.

A Pós Graduação da FOB-USP, e seus funcionários, pela responsabilidade, apoio e cuidado que sempre tiveram com seus alunos.

A Bete, Hermínia, Ângela bem como todos os alunos do "Primeiro Emprego" e todos os funcionários da Casa do Garoto (Bauru-SP), pela compreensão, respeito e companheirismo a mim dispensados durante a realização do meu trabalho. 


\section{“... FAZER DA MINHA VIDA SEMPRE O MEU PASSEIO ÚNICO E AO MESMO TEMPO FAZER DELA O MEU CAMINHO SÓ, ÚNICO”...}




\section{RESUMO}

Segundo o Estatuto da Criança e do Adolescente (ECA), a adolescência é situada entre 12 e 18 anos. O Brasil sendo um país onde existe grande desigualdade social, os jovens de classe baixa procuram o mercado de trabalho precocemente, para obter uma renda familiar maior e ajudar em casa. Considerando o defasado ensino brasileiro atual, e a falta de estruturas necessárias para a contratação de um fonoaudiólogo, tem-se como conseqüência o desenvolvimento de adolescentes com dificuldades de comunicação escrita não detectadas precocemente, assim, quando os jovens se deparam com o mercado de trabalho, em busca do seu primeiro emprego, encontram dificuldades relacionadas à sua comunicação. Este trabalho teve como objetivo geral, implantar uma Oficina de Aprimoramento da Comunicação Escrita, em adolescentes freqüentadores do Curso "Primeiro Emprego" oferecido pela Diocese de Bauru Divino Espírito Santo (Casa do Garoto Rogacionista) na cidade de Bauru-SP no ano letivo de 2008, devido a estes jovens apresentarem uma escrita defasada, que pode interferir direta ou indiretamente na seleção de uma vaga de emprego. As Oficinas foram realizadas no período de 8 semanas, e após a realização destas, podê-se encontrar dados estatisticamente significantes quando falamos em elaboração de texto. Após este trabalho também foi observado melhora quanto a coesão, uso de pontuação, bem como, sintaxe, e também a opinião positiva dos adolescentes em relação ao oferecimento das oficinas realizadas.

Palavras-chave: Adolescentes, Mercado de Trabalho, Comunicação 


\begin{abstract}
According to the Statute of the Child and Adolescent (ECA), adolescence is located between 12 and 18 years. Brazil is a country where there is great social inequality, low-class young people looking for the labor market early, to get a higher family income and help at home. Considering the current Brazilian low education, and lack of necessary structures for the hiring of a speech pathologist, as a consequence has been development of adolescents with difficulties in written communication not detected earler, so, when young people are faced with the labor market, in search of their first jobs, have difficulty relating to their communication. This study aimed to rule, establish an Office of Improving Communication Writing in adolescents attend Course "First Job" offered by the Diocese of Allahabad Holy Ghost (House of Boy Rogacionista) in the city of Bauru, Sao Paulo in the 2008 school year Because these young people to submit a written low, which may interfere directly or indirectly in the selection of a wave of employment. The workshops were held during the period of 8 weeks, and after the completion of these, one can find data statistically significant when we talk about drafting a text. After this work was also observed improvement in cohesion, use of punctuation, and syntax, and also the positive view of adolescents in relation to the offering of workshops.
\end{abstract}

Keywords: Teenagers, Labour Market, Communication 


\section{LISTA DE TABELAS}

Tabela 1 -Censo Escolar 2006............................................................... 40

Tabela 2 - Principais diferenças entre fala e escrita............................... 59

Tabela 3 - Idade dos sujeitos......................................................... 89

Tabela 4 - Escolaridade dos sujeitos................................................... 90

Tabela 5 - Concepção do aluno em relação às habilidades e dificuldades no que diz respeito as áreas de atuação fonoaudiológicas............................................................. 93

Tabela 6 - Comparação entre escrita espontânea inicial e final em relação a construção de texto............................................................... 97

Tabela 7 - Comparação entre o número de parágrafos encontrados na Escrita Espontânea inicial e final.......................................... 97

Tabela 8 - Comparação entre Ditado e Escrita Espontânea Inicial com Ditado e escrita Espontânea Final em relação aos erros ortográficos encontrados...................................................... 98

Tabela 9- Comparação entre Escrita Espontânea Inicial Final em relação aos erros ortográficos

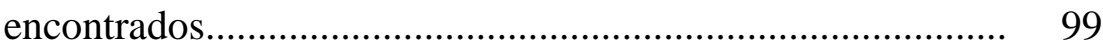

Tabela 10 - Percepção dos adolescentes em relação ao trabalho de Aprimoramento da Comunicação oral e escrita.................... 100 


\section{LISTA DE ABREVIATURAS}

EM Ensino Médio

EF Ensino Fundamental

n Número de sujeitos

ns Diferença estatisticamente não significante

dp Desvio Padrão

p Probabilidade 


\section{SUMÁRIO}

\section{Resumo}

1. Introdução

2. Revisão de Literatura .33

2.1. Adolescentes. .33

2.2. O Trabalho de Crianças e Adolescentes no Brasil .35

2.3. O Sistema de ensino no Brasil. 39

2.3.1. Parâmetros Curriculares Nacionais. .42

2.3.2. Parâmetros Curriculares Nacionais no Ensino Fundamental.

2.3.3. Parâmetros Curriculares Nacionais no Ensino Médio .45

2.4. O Papel do Fonoaudiólogo na escola. .45

2.5. O processo de comunicação oral e escrita. .50

2.5.1. Linguagem .50

2.5.2. Comunicação. .51

2.5.3. Tipos de Comunicação. .53

2.5.3.1. Fala e a Escrita. .56

2.5.3.2. O Processo de Aquisição da Escrita .59 


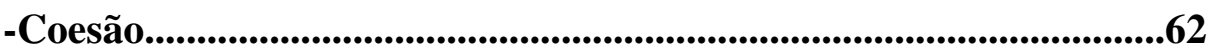

-Coerência......................................................................................................63

-Estrutura sintática...........................................................................64

-Léxico.....................................................................................64

-Uso de Pontuação...................................................................................65

-Erros Ortográficos.............................................................................................66

2.5.3.4. Leitura...............................................................................................67

2.5.4. Aprimoramento da Comunicação ........................................................................68

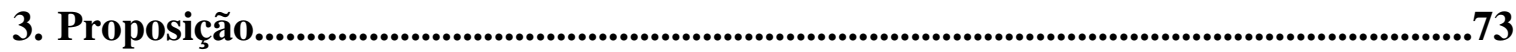

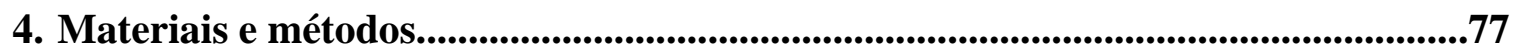

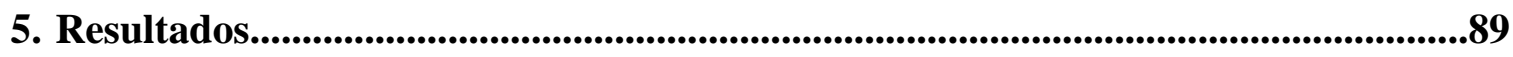

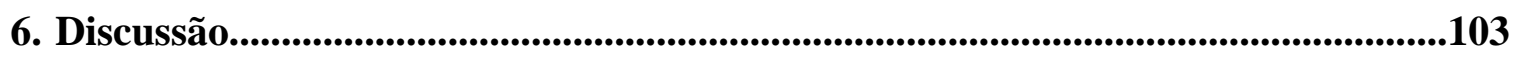

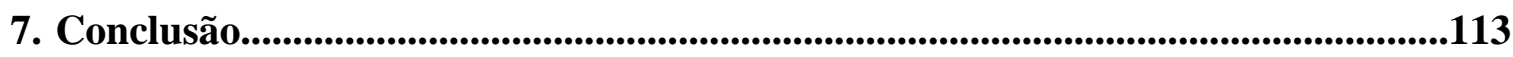

8. Referências Bibliográficas ......................................................................................................117

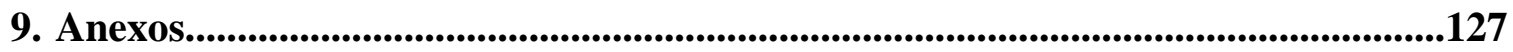

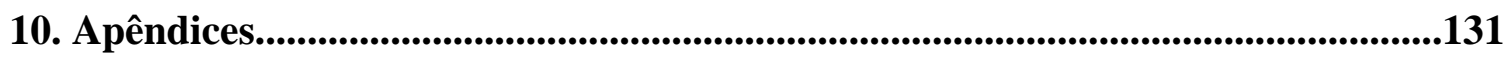




\section{INTRODUÇÃO}

A crise econômica-política brasileira agravou o estado de pobreza da população, fazendo crescer o percentual de famílias que ganham até dois salários mínimos e enfrentam sérios problemas para sua sobrevivência (OLIVEIRA; ROBAZZI, 2001).

Sob este aspecto, e ainda acrescido de outros fatores psicológicos, sociais e familiares, que contribuem para o desajustamento cada vez maior no desenvolvimento da criança e adolescente como pessoa e como integrante de uma sociedade, é que diversas instituições vêm tentando com seus recursos, contornar esse problema social (OLIVEIRA; ROBAZZI, 2001).

O trabalho de crianças e de adolescentes tem sido objeto de estudos que tratam do tema com enfoques teóricos distintos, os quais mostram indagação em função das conseqüências que o trabalho acarreta no desenvolvimento psicológico e intelectual e na escolarização de crianças e adolescentes. Alguns estudos, dentre os quais os de Alvim e Valladares (1988); Gomes (1998); Passetti (1991), discutiram e analisaram a legislação acerca do trabalho na infância e na adolescência até sua regulamentação atual com a criação do ECA (Estatuto da Criança e do Adolescente).

O ECA, lei federal de 13 de julho de 1990, criou condições para assegurar à criança e ao adolescente o cumprimento dos direitos presentes na Constituição de 1988, procurando defendê-los da exploração nas relações de trabalho. Para tal, entre outras medidas, o ECA estabeleceu distinção entre faixas etárias, levando em conta as diversas fases de desenvolvimento. De acordo com o ECA, crianças e adolescentes são cidadãos em fase de desenvolvimento e, por isso, tem dificuldade em algumas situações de fazer valer plenamente seus direitos, necessitando da proteção da família e do Estado (BRASIL, 2001).

Podemos encontrar no ECA, a regulamentação que consta de informações necessárias sobre a entrada do menor no mercado de trabalho a partir de 16 anos, baseando-se em um conjunto de regras e no estabelecimento de condições em que adolescentes podem trabalhar, 
como por exemplo: idade, horário de trabalho, disponibilizando tempo para o adolescente freqüentar escola, bem como a não aprovação de trabalhos considerados insalubres e ao horário noturno, devido a serem estes considerados prejudiciais ao crescimento e à saúde deste trabalhador (ALVIM, 2001).

Nesse sentido, alguns estudos mostram como o trabalho de crianças e adolescentes, é importante para ampliar os rendimentos dos pais e para assegurar a sobrevivência da família, bem como para impedir que os filhos fiquem "na rua” e para evitar seu envolvimento com o mundo da marginalidade, que envolve a possibilidade de consumo e de tráfico de drogas (OLIVEIRA; ROBAZZI, 2001).

Por outro lado, o trabalho pode propiciar o amadurecimento psicológico e intelectual dos adolescentes e também atuar como forma de socialização, que pode completar a ação da escola. Além disso, a busca por emprego também está associada ao desejo de conquistar a autonomia, liberdade e também de consumo de bens que os pais não podem proporcionar (CERVINI; BURGER (1991); DAUSTER (1992); MADEIRA; BERCOVICH (1992).

Levando em consideração que os adolescentes de classe desfavorecida procuram emprego antes mesmo de completar a maioridade, este estudo teve como objetivo geral, implantar uma Oficina de Aprimoramento da Comunicação Escrita, em adolescentes freqüentadores do Curso “Primeiro Emprego” oferecido pela Diocese de Bauru Divino Espírito Santo (Casa do Garoto Rogacionista) na cidade de Bauru-SP no ano letivo de 2008. 


\section{REVISÃO DE LITERATURA}

\subsection{Adolescentes}

Segundo Mussen (1995), etiologicamente o termo adolescência vem do verbo latino “adolescere” (ad=para e olescere=crescer), estando implícito neste a condição ou processo de crescimento, apontando para as mudanças que começariam com o início da puberdade e terminariam quando as responsabilidades adultas fossem assumidas. Este autor também relata que a adolescência “começa na biologia e termina na cultura”.

Segundo Ferreira (1995) a adolescência é o "período da vida humana que sucede à infância, começa com a puberdade, e se caracteriza por uma série de mudanças corporais e psicológicas”.

Adolescência, segundo Doron (1998), é uma fase de reestruturação afetiva e intelectual da personalidade, um processo de individuação e de metabolização das transformações fisiológicas ligadas à integração do corpo sexuado. As mudanças, que nesse período são muitas, são sustentadas pela revivescência do movimento de separação-individuação da primeira infância; pela reativação do conflito edipiano; pelo desligamento das imagens parentais infantis e a religação com novos objetos libidinais; por relações defensivas com o ideal do ego e com pulsões para estabelecer um novo equilíbrio narcísico (recalque, deslocamento, recusa, clivagem, intelectualização, ascetismo, projeção). O adolescente é assim uma moratória infiltrada por uma problemática de identidade: o ideal consiste em negociar lutos, as perdas e as desilusões até o momento em que o sujeito pode assumir sua separação e sua diferenciação na autonomia.

De acordo com os Brasil (1998), é na Adolescência que ocorrem as transformações corporais, com pequena variação, provocando desajustes na locomoção e coordenação de movimentos, demandando adaptações constantes; a sexualidade apresenta sensações, desejos e 
possibilidades até então não experimentadas; também acontecem mudanças significativas na forma do corpo, no timbre da voz e na postura. Assim, impondo ao adolescente a necessidade de reformulação de sua auto-imagem, já as demais transformações, variam de cultura para cultura, de grupo social para grupo social e de sujeito para sujeito.

Segundo Blos (1998), a adolescência se caracteriza pelas mudanças físicas, as quais se refletem em todas as facetas do comportamento; e também num plano mais sutil e inconsciente, o chamado processo de pubescência, que afeta o desenvolvimento de seus interesses, seu comportamento social e qualidade de vida afetiva.

Para Villarreal (2001), este período leva à maturação física e inclusive à possibilidade da sexualidade adulta, procriativa, concomitantemente às importantes mudanças que estão se produzindo na estrutura psíquica. Este mesmo autor relata que o fenômeno da adolescência só é encontrado no desenvolvimento do ser humano, e pode ser estudado de ângulos diferentes, sendo um deles, ver a adolescência como uma segunda fase de separação das figuras parentais.

Canongia (2000) relata que a adolescência é uma fase de grandes transformações, tanto física, quanto psíquicas, em que existe a necessidade de se tornar independente.

De acordo com o Estatuto da Criança e do Adolescente (ECA), a adolescência é situada entre 12 e 18 anos (BRASIL, 2001).

Segundo Traverso-Yépez e Pinheiro (2002), a Organização Mundial de Saúde (OMS), define que a adolescência se compreende dos 10 aos 19 anos, sendo este, critério adotado, no Brasil, pelo Ministério da Saúde e pelo Instituto Brasileiro de Geografia e Estatística (IBGE). Esta oscilação deve-se ao fato de que o critério etário não pode ser tomado isoladamente para caracterizar essa fase.

No Brasil, país em que a desigualdade social convive com a diversidade cultural, a adolescência apresenta características específicas, que variam de acordo com a camada ou 
classe social, com o gênero, com o período histórico e com a cultura em que o adolescente está inserido (ALVES-MAZZOTTI, 2002).

A situação de desigualdade social, política e econômica encontrada no Brasil têm influência direta na dinâmica familiar e no aumento do número de crianças e adolescentes em situação de risco social e pessoal (GONTIJO; MEDEIROS, 2004). Devido a desigualdade social que existe em nosso país, podemos ver muitos adolescentes da classe social considerada desfavorável à procura de um emprego.

Mauro (1995), informou que nas famílias de classes populares, é na adolescência, se não desde a infância, que os filhos são inseridos no mercado de trabalho, em função das dificuldades financeiras da família.

\subsection{Trabalho das crianças e dos adolescentes no Brasil}

Segundo Lopes (1996), de acordo com o art.7º, inciso XXXIII, da Constituição Federal e o Estatuto da Criança e do Adolescente (ECA), estes, estabelecem a proibição do trabalho noturno, perigoso, insalubre e penoso aos menores de 18 anos, fazendo com que a Consolidação das Leis Trabalhistas (CLT) especifique a natureza destes:

Trabalho Noturno: “realizado entre 22:00h de um dia e 5:00h do outro dia”(art.73);

Trabalho Perigoso: “aquele que por sua natureza, condição ou método de trabalho, impliquem o contato permanente com inflamáveis e explosivos em condições de riscos acentuado”(Art 193);

Trabalho Insalubre: “Aqueles que por sua natureza, condições ou método de trabalho exponham os empregados a agentes nocivos à saúde, acima dos limites de tolerância do agente e do tempo de exposição a seus efeitos” (Art. 189); 
Trabalho Penoso: “serviço que demande o emprego de força muscular superior a 20kg para trabalho contínuo ou 25kg para trabalho ocasional” (Art.390) (BRASIL, 2007).

De acordo com a Legislação Brasileira, só se permite o trabalho de adolescentes a partir dos 16 anos de idade, admitindo que ele seja exercido sob 3 formas: emprego, estágio e aprendizado (LOPES, 1996).

O adolescente empregado tem assegurado todos os direitos trabalhistas previstos em lei, tais como, salário-mínimo, carteira assinada, descanso semanal remunerado, jornada de trabalho de 8 horas diárias e 44 semanais, $13^{\circ}$. salário, aviso prévio, FGTS, contagem de tempo para aposentadoria e férias anuais. Além disso, a duração de suas atividades deve sempre permitir uma efetiva freqüência às aulas, sendo o empregador obrigado a conceder o tempo que for necessário à sua formação escolar (LOPES, 1996).

Os Adolescentes estagiários devem estar necessariamente, cursando o ensino médio de formação técnica ou o ensino superior. Neste caso, a atividade profissional, apenas complementa, na prática, a formação teórica escolar, não estabelecendo vínculo empregatício e nem gerando os direitos trabalhistas e previdenciários (LOPES, 1996).

Já o Adolescente aprendiz, é aquele que se profissionaliza trabalhando, dentro de um processo educacional previsto em lei, em que lhe são ministrados, pelos órgãos competentes (Senai, Senac e Senar), cursos que têm por objetivo levar-lhe o conhecimento teórico-prático de um determinado ofício, cujo exercício exige uma pré-qualificação. Estes têm os mesmos direitos de todos os demais empregados, além disso, deverá ter sua Carteira de Trabalho e Providência Social anotada quanto a seu contrato de trabalho, e também seu acesso a escola garantido (LOPES, 1996).

De acordo com os dados acima, sabemos que o adolescente pode trabalhar, porém, devese respeitar todas as leis citadas na Cartilha do Trabalhador Adolescente, garantindo todos seus direitos. 
Embora a preocupação e o combate ao trabalho precoce tenham um apelo humanitário, este, continua existindo e proliferando-se (VEIGA, 1998).

Inseridos precocemente no mercado de trabalho, estes jovens realizam uma variada gama de atividades, tornando-se mão de obra desqualificada e barata, seja no setor primário da economia (corte de cana, sisal, extração de carvão, colheitas...) no secundário, (aprendizes na industria em geral), no terciário (boys, babás, guarda-mirins, patrulheirismo, empregadas domésticas) e na chamada "economia informal” (trabalho de rua, camelô, baleiro...) em atividades domésticas (nas quais predominam as meninas) e até mesmo em ramos ilegais, como tráfico de drogas e prostituição (NETO, 1998).

O trabalho dessas vítimas do capital não é voluntário e muito menos prazeroso. Na verdade sua atividade é monótona, braçal, repetitiva, desinteressante e desestimulante. No entanto, o pouco dinheiro que arrecadam, é de vital importância para eles e para suas famílias (NETO, 1998).

Santos (1997) relatou que os adolescentes que trabalham precocemente, são diretamente prejudicados em seu rendimento escolar e sofrem seguidos agravos à sua saúde, não se constituindo nem em estudantes que trabalham, nem em trabalhadores que estudam.

O trabalho de crianças e de adolescentes tem sido objeto de estudos que tratam do tema com enfoques teóricos distintos, os quais têm suscitado indagações em função das conseqüências que o trabalho acarreta no desenvolvimento psicológico e intelectual e na escolarização de crianças e adolescentes (SANTOS, 1997).

Estudos como os de Alvim e Valladares (1998), Gomes (1998) e Passetti (1991) discutiram e analisaram a legislação acerca do trabalho na infância e na adolescência até sua regulamentação atual com a criação do ECA.

De acordo com a lei federal de 13 de julho de 1990, o ECA criou condições para assegurar à criança e ao adolescente o cumprimento dos direitos presentes na Constituição de 
1988, procurando defendê-los da exploração nas relações de trabalho. Foram estabelecidas faixas etárias, levando em conta as diferentes fases de desenvolvimento, considerando como criança, o indivíduo com idade até 12 anos incompletos e como adolescentes, os que estão entre 12 e 18 anos. De acordo com tal estatuto, crianças e adolescentes são cidadãos e sujeitos de direito em fase de desenvolvimento e, por isso, não têm condições de fazer valer plenamente seus direitos ou a própria sobrevivência, necessitando da proteção da família e do Estado (BRASIL, 2001).

Concomitantemente às regulamentações de inclusão de crianças e adolescentes no mercado de trabalho, é importante considerar as condições sociais e econômicas em que vivem as famílias.

Alguns autores levantaram dados que mostram como o trabalho de crianças e adolescentes é importante para ampliar os rendimentos dos pais e para assegurar a sobrevivência da família (BILAC, 1978; NETO, 1982; MACHADO NETO, 1979). Além disso, esse trabalho impede que eles permaneçam nas ruas evitando, assim, que se envolvam com o mundo da marginalidade, podendo fazer uso de drogas ou mesmo comercializá-la (ALVESMAZZOTTI, 2002; ALVIM, 2001; DAUSTER, 1992). De acordo com Mauro (1995), o trabalho propicia ao adolescente um amadurecimento psicológico e até intelectual.

Segundo Cervini e Burger (1991), Dauster (1992) e Madeira e Bercovich (1992), a condição de produtor de rendimentos não resulta apenas da situação de pobreza, mas, também, do desejo de conquista de autonomia, liberdade e do consumo de bens que os pais não podem proporcionar. Sendo assim, há diferentes motivações para o ingresso de crianças e adolescentes no mercado de trabalho.

Para Romanelli (1997), essas classes podem ser consideradas como constituídas pela população pobre dos centros urbanos, que vive em condições financeiras precárias, decorrentes 
da reduzida qualificação ocupacional e da baixa escolaridade de seus integrantes, que têm acesso limitado aos serviços públicos, como educação e saúde.

Mauro (1995) informou que nas famílias de classes populares, é na adolescência, se não desde a infância, que os filhos são inseridos no mercado de trabalho, em função das dificuldades financeiras da família.

De acordo com Vicente (1994, p.57), “o processo de profissionalização não pode impedir o jovem de estudar e, principalmente, não pode impedi-lo de construir um projeto de vida”.

Em nosso país, existem instituições e/ou programas governamentais, não-governamentais ou religiosos que estão à disposição destes jovens prestando os mais diversos serviços, tais como: fornecimento de alimentação, educação, lazer e prestação de cuidados com a higiene e a saúde. Bandeira et al. (1994) apontaram, em seu estudo com adolescentes, que a quase totalidade deles referiam-se às instituições de recreação e/ou oficinas profissionalizantes como contextos importantes no seu dia-a-dia. Estes resultados confirmaram os dados obtidos por Forster et al. (1992), que reafirmaram a capacidade de envolvimento dos jovens em situação carentes com pessoas e instituições. Este aspecto também foi enfatizado por Brito (1999), que escreveu sobre o importante papel desempenhado pelas instituições de atendimento, na rede de apoio social e afetivo a esses adolescentes.

\subsection{O Sistema de ensino no Brasil}

De acordo com Akkari (1996), o ensino público brasileiro começou a se estruturar a partir da constituição de 1824, que reconhecia o direito de todo cidadão a uma educação primária. No ano de 1930, criou-se um ministério da educação. Em seguida, a lei de diretriz da educação de 1962 que instituiu três tipos de escolas públicas (federais, estaduais e municipais). Em 1988, estabeleceu-se a convivência das redes pública e particular, onde para a rede 
particular, uma distinção foi estabelecida entre instituições com e sem fins lucrativos (escolas comunitárias, filantrópicas e confessionais).

No Brasil, de acordo com o Ministério da Educação (2006), obtivemos os seguintes dados em relação ao número de aluno inserido em diferentes etapas da Educação Básica:

Tabela 1: Censo Escolar 2006

\begin{tabular}{c|c|}
\hline $\begin{array}{c}\text { Etapas/Modalidades de } \\
\text { Educação Básica }\end{array}$ & 2006 \\
\hline Total & 55942047 \\
& 7016095 \\
Educação Infantil & 1427942 \\
Creche & 5588153 \\
Pré-escola & 33282663 \\
Ensino Fundamental & 8906820 \\
Ensino Médio & 5616291 \\
EJA & 4861390 \\
Presencial & 754901 \\
Semipresencial & 375488 \\
Educação Especial & 744690 \\
Educação Profissional & \\
\hline Fonte: MEC/INEP. &
\end{tabular}

O sistema de ensino no Brasil é descentralizado e divide-se em educação básica e superior. A educação básica abrange a educação infantil, o ensino fundamental e o ensino médio. Segundo a atual legislação, compete aos municípios atuar prioritariamente no ensino fundamental e na educação infantil e aos estados e ao Distrito Federal nos ensinos fundamental e médio. Já o Governo Federal exerce função supletiva, prestando assistência técnica e financeira aos estados, ao Distrito Federal e aos municípios (MINISTÉRIO DA EDUCAÇÃO, 2008).

A primeira etapa da educação básica é a infantil, que é oferecida em creches para crianças de até três anos de idade e em pré-escolas para crianças de 4 a 6 anos. De acordo com dados do MEC, a “educação infantil, primeira etapa da educação básica tem como finalidade o 
desenvolvimento integral da criança até seis anos de idade, em seus aspectos físico, psicológico, intelectual e social, complementando a ação da família e da comunidade. Esta é oferecida em: creches, ou entidades equivalentes, para crianças de até três anos de idade; préescolas, para crianças de quatro a seis anos de idade.” [LDB art. 29 e 30] (MINISTÉRIO DA EDUCAÇÃO, 2008).

No que se refere ao Ensino Fundamental, de acordo com a Lei das Diretrizes e Bases da Educação Nacional (LDB) em seu Art.5º, esta, afirma que "o acesso ao ensino fundamental é direito público subjetivo, podendo qualquer cidadão, grupo de cidadãos, associação comunitária, organização sindical, entidade de classe ou outra legalmente constituída, e, ainda, o Ministério Público, acionar o Poder Público para exigi-lo". A LDB, também coloca que é dever dos pais ou responsáveis efetuar a matrícula dos menores neste nível de ensino, a partir dos sete anos (MINISTÉRIO DA EDUCAÇÃO, 2008).

Já o Art. 32 afirma que "o ensino fundamental obrigatório, com duração de 9 (nove) anos, gratuito na escola pública, inicia-se aos 6 (seis) anos de idade, e tem como objetivo a formação básica do cidadão, mediante: I - o desenvolvimento da capacidade de aprender, tendo como meios básicos o pleno domínio da leitura, da escrita e do cálculo; II - a compreensão do ambiente natural e social, do sistema político, da tecnologia, das artes e dos valores em que se fundamenta a sociedade; III - o desenvolvimento da capacidade de aprendizagem, tendo em vista a aquisição de conhecimentos e habilidades e a formação de atitudes e valores; IV - o fortalecimento dos vínculos de família, dos laços de solidariedade humana e de tolerância recíproca em que se assenta a vida social" (Redação dada pela Lei $\mathrm{n}^{0}$ 11.274, de 2006) (MINISTÉRIO DA EDUCAÇÃO, 2008).

Já o Ensino Médio, etapa final da educação básica, tem duração mínima de três anos e atende a formação geral do aluno, podendo incluir programas de preparação geral para o 
trabalho e, facultativamente, a habilitação profissional (MINISTÉRIO DA EDUCAÇÃO, 2008).

Além do Ensino Básico, também integram a educação formal a educação especial, para os portadores de necessidades especiais; a educação de jovens e adultos, destinada àqueles que não tiveram acesso ou continuidade de estudos no ensino fundamental e médio na idade apropriada; a educação profissional, integrada às diferentes formas de educação, ao trabalho, às ciências e à tecnologia. Tem-se também o ensino de nível técnico. Já a educação superior abrange os cursos de graduação nas diferentes áreas profissionais, abertos a candidatos que tenham concluído o ensino médio ou equivalente e tenham sido classificados em processos seletivos. Também faz parte desse nível de ensino a pós-graduação, que compreende programas de mestrado e doutorado e cursos de especialização (MINISTÉRIO DA EDUCAÇÃO, 2008).

\subsubsection{Parâmetros Curriculares Nacionais.}

Os Parâmetros Curriculares Nacionais, foram elaborados, procurando respeitar as diversidades regionais, culturais, políticas existentes em nosso país e, também, levando em consideração, a necessidade de construir referências nacionais comuns ao processo educativo em todas as regiões brasileiras. Assim, pretendendo criar condições, nas escolas, que permitiriam aos jovens ter acesso ao conjunto de conhecimentos socialmente elaborados e reconhecidos como necessários ao exercício da cidadania.

Levando em consideração a divisão entre os ensinos brasileiros citados anteriormente, falaremos abaixo detalhadamente sobre os parâmetros encontrados quando falamos do Ensino Fundamental (no período de $5^{\mathrm{a}}$. a $9^{\mathrm{a}}$. série) e do Ensino Médio $\left(1^{\circ}\right.$., $2^{\circ}$. e $3^{\circ}$. Ano) em relação ao aprendizado da Língua Portuguesa.

No que diz respeito ao Ensino Fundamental, podemos encontrar nesta fase escolar, alunos que apresentam em média de 11 a 15 anos; no Ensino Médio, podemos encontrar alunos 
com 15 a 18 anos, porém devido a possíveis repetições escolares, podemos também encontrar alunos com idade superior as demais mencionadas.

Este é um período da vida em que o desenvolvimento é marcado pelo processo de (re)constituição da identidade, para o qual concorrem transformações corporais, afetivoemocionais, cognitivas e socioculturais (BRASIL, 1998).

\subsubsection{Parâmetros Curriculares Nacionais no Ensino Fundamental}

Considerando a Disciplina da Língua Portuguesa, a área relacionada diretamente com o presente trabalho, segue abaixo o que se espera destes alunos em relação ao processo de escrita. Espera-se no Ensino Fundamental que o aluno, amplie, progressivamente, o conjunto de conhecimentos discursivos, semânticos e gramaticais envolvidos na construção dos sentidos do texto; seja capaz de reconhecer a contribuição complementar dos elementos não verbais como por exemplo (gestos, expressões faciais, postura corporal); utilize a linguagem escrita, quando for necessário, como apoio para registro, documentação e análise, e também que amplie a capacidade de reconhecer as intenções do enunciador, sendo capaz de aderir ou recusar as posições ideológicas sustentadas em seu discurso (BRASIL, 1998).

No que diz respeito ao processo de leitura de textos escritos espera-se que: o aluno saiba selecionar textos segundo seu interesse e necessidade; leia, de maneira autônoma, textos de gêneros e temas com os quais tenha construído familiaridade; seja receptivo a textos que rompam com seu universo de expectativas, por meio de leituras desafiadoras para sua condição atual, apoiando-se em marcas formais do próprio texto ou em orientações oferecidas pelo professor; troque conhecimentos com outros leitores a respeito dos textos lidos, sabendo criticar tanto o assunto do texto como de sua prática enquanto leitor; compreender a leitura em suas diferentes dimensões (BRASIL, 1998). 
Quanto à produção de textos escritos, os parâmetros esperam que o aluno nesta fase seja capaz de elaborar diferentes tipos de textos, sabendo relevar as partes e os tópicos em relação ao tema e propósitos do texto. Também deve-se saber estabelecer o tema; fazer inicialmente um levantamento de idéias e dados, elaborar um planejamento onde se deve conter um rascunho, revisão e versão final, e fazer uso de mecanismos discursivos e lingüísticos de coerência e coesão textuais, conforme o gênero e os propósitos do texto, desenvolvendo diferentes critérios: de manutenção da continuidade do tema; da utilização de marcas de segmentação em função do projeto textual: título e subtítulo; uso de parágrafo; uso de pontuação (ponto, vírgula, ponto-e-vírgula, dois-pontos, ponto-de-exclamação, ponto-deinterrogação, reticências) entre outros sinais gráficos (aspas, travessão, parênteses) (BRASIL,1998).

Já em relação a produção de textos orais, estes alunos devem ter em mente a capacidade de um planejamento prévio da fala em função da intencionalidade do locutor, das características do receptor, das exigências da situação e dos objetivos estabelecidos; saber selecionar adequadamente o gênero, recursos discursivos, semânticos e gramaticais, prosódicos e gestuais e saber ajustar a fala em função da reação dos interlocutores (BRASIL, 1998).

De acordo com os Parâmetros Curriculares Nacionais, os últimos anos do ensino fundamental têm papel decisivo na formação de leitores, pois é neste período que muitos alunos desistem de ler por não conseguirem responder às demandas de leitura colocadas pela escola, ou passam a utilizar os procedimentos construídos nos ciclos anteriores para lidar com os desafios postos pela leitura (BRASIL, 1998). 


\subsubsection{Parâmetros Curriculares Nacionais no Ensino Médio}

Levando em consideração que os princípios básicos da língua portuguesa foram aprendidos durante o ensino fundamental, é de competência do ensino médio oferecer aos estudantes oportunidades de uma compreensão mais profunda dos mecanismos que regulam nossa língua, tendo como ponto de apoio, os textos escritos, especialmente os literários (BRASIL, 1998).

As competências e habilidades propostas pelos Parâmetros Curriculares Nacionais para o Ensino Médio, oferece ao aluno, desenvolver seu potencial crítico, bem como a percepção das múltiplas possibilidades de expressão lingüística e também ampliar a capacitação como leitor efetivo, dos mais diversos textos representativos de nossa cultura. Também o aluno deve ter meios para ampliar e articular conhecimentos e competências que possam ser mobilizadas nas inúmeras situações de uso da língua com que se depara, na família, entre amigos, na escola e no mundo do trabalho (BRASIL, 1998).

Desta forma, nesta etapa da vida, o adolescente, freqüentador do Ensino Médio, quando falamos da Língua Portuguesa, tem como parâmetros nesta etapa, enriquecer sua escrita em conteúdo, já que todas as estruturas da língua já deveriam ter sido aprendidas durante os estudos realizados no Ensino Fundamental (BRASIL, 1998).

\subsection{O papel do Fonoaudiólogo no ensino no Brasil}

Segundo a lei 6965, no artigo 1, "Fonoaudiólogo é o profissional com graduação plena que atua em pesquisa, prevenção, avaliação e terapia na área da comunicação oral, escrita, voz e audição, bem como em aperfeiçoamento dos padrões de fala e da voz” (BRASIL, 2004). 
Entre as responsabilidades de competência do Fonoaudiólogo, podemos identificar algumas de suas áreas de atuação, são elas: “desenvolver ações de saúde coletiva dos aspectos fonoaudiológicos; realizar diagnóstico de Fonoaudiologia; executar terapia (habilitação/reabilitação); orientar pacientes, clientes internos e externos, familiares e cuidadores; monitorar desempenho do paciente ou cliente (seguimento); aperfeiçoar a comunicação humana; exercer atividades de ensino; desenvolver pesquisas; administrar recursos humanos, financeiros e materiais (BRASIL, 2004).

No capítulo II, artigo $3^{\circ}$., é estabelecido que : “É de competência do fonoaudiólogo descrever trabalho de prevenção no que se refere à área de comunicação escrita e oral, voz e audição, participar da equipe de orientação e planejamento escolar, inserindo aspectos preventivos ligados a assuntos fonoaudiológicos” (BRASIL, 2004).

Guedes (1997) relata que após estabelecida esta lei, fica claro que atuação do Fonoaudiólogo na escolar visa ser de caráter preventivo em relação ao desenvolvimento da comunicação oral, escrita, voz e audição.

De acordo com Pereira, Santos e Osborn (2000), a comunicação humana pode ser entendida como um processo de transmissão e recepção de mensagens, por meio da linguagem falada e da escrita, sendo que o desenvolvimento deste processo permite a integração individual e social da criança e faz parte do processo de educação.

Os mesmo autores afirmam ainda, que a população que freqüenta a escola ter um convívio de várias horas por dia, durante anos, a escola tem um papel não apenas formativo, mais informativo também. Essas pessoas sofrem influência tanto do ambiente escolar como familiar através da troca de experiência que podem ser positivas ou negativas para o seu desenvolvimento.

Sacalosky, Alavarsi e Guerra (2000), colocam que a escola é um espaço de transformação da sociedade, devido ao fato de oferecer ao indivíduo possibilidades para 
construir sua cidadania. Levando em consideração este dado, se vê necessário, no âmbito escolar, a formação de uma equipe multidisciplinar formada por psicopedagogos, psicólogos e fonoaudiólogos, para, se necessário suprir as diversas dificuldades que poderão aparecer neste ambiente, bem como uma atuação de caráter preventivo para que não venham aparecer quaisquer tipo de alteração nos alunos.

Kyrrillos, Martins e Ferreira (1997) relataram que desde que nascemos estamos expostos a um meio onde se tem muitos estímulos, os quais direta e indiretamente influenciam nosso comportamento. Tais comportamentos são aprendidos também na escola, e proporciona uma gama de novas trocas de experiências sendo que nela a criança desenvolve seu papel de aprendiz. As autoras ainda completam que a escola divide com os pais a responsabilidade de organizar as novas experiências dessas crianças.

Sendo o fonoaudiólogo o profissional que atua mais especificamente com a linguagem e seus distúrbios, o trabalho tradicional da Fonoaudiologia era tratar dos distúrbios da comunicação já instalados. Porém Kyrrilos, Martins e Ferreira (1997), relatam que recentemente começaram a dar importância na prevenção primária dos indivíduos, com a preocupação de evitar que os distúrbios instalem-se e assim acontecer o desenvolvimento normal da comunicação.

De acordo com Zorzi (1999), a fonoaudiologia escolar é a área que visa ações de caráter preventivo, para auxiliar na profilaxia e também na manutenção de saúde fonoaudiológica. Esta, tem como objetivo promover reflexões junto aos professores, contribuindo para uma melhor integração entre a escola, o aluno e a família.

Este mesmo autor relatou ainda que a fonoaudiologia na área educacional, tem como objetivo não somente detectar as alterações da linguagem oral e escrita, mas também oferecer possibilidades para criar condições favoráveis e eficazes para que as capacidades de cada um possam ser exploradas ao máximo, não apenas no sentido de eliminar problemas, mas sim 
acreditando que determinadas situações e experiências podem sim facilitar o desenvolvimento e a aprendizagem.

De acordo com Pacheco e Caraça (1989), a atuação do fonoaudiólogo na escola é muito ampla. Entre suas atuações, o fonoaudiólogo quando inserido na escola pode também atuar dando orientações e sugestões técnicas aos professores, assim, auxilia a preparar as crianças para a alfabetização propriamente dita, bem como para etapas posteriores a esta. Esta atuação, que tem como caráter preventivo, colaborar para prevenir possíveis problemas que poderão surgir.

Collaço (1991) relatou a diferença entre a fonoaudiologia escolar e o fonoaudiólogo clínico. A primeira apresenta um enfoque preventivo e a atuação é planejada em equipe e desenvolvida pelo professor em sala de aula, já a segunda, o profissional, trata da patologia que o indivíduo apresenta, podendo ser esta individualmente ou em grupos.

O mesmo autor relatou também a importância da interligação das ações dos fonoaudiólogos com outros profissionais, tais como: psicólogo, orientador educacional, orientadores de áreas de estudo, etc. Para ele, quando se tem um bom vinculo entre diversos profissionais, pode-se chegar a conclusão de qual será a melhor conduta e assim passá-la para o professor, já que é o único que tem contato mais direto com o aluno.

Para Kyrillos, Martins e Ferreiran (1997), a experiência da atuação do fonoaudiólogo juntamente com a do professor, com base na integração de conhecimentos de ambos, só têm a contribuir para o desenvolvimento dos alunos.

O trabalho conjunto Fono-Professor, pode ser benéfico devido ao Fonoaudiólogo poder passar orientações aos professores, com o intuito de fornecer-lhes informações quanto ao desenvolvimento normal, características dos distúrbios da comunicação bem como, das manifestações que podem ser observadas em sala de aula. Assim, surgiu a proposta de oferecer conhecimentos básicos da fonoaudiologia para dentro da escola, pois desta maneira, podemos 
favorecer a inter-relação do fonoaudiólogo junto com o professor (SACALOSKI; ALAVARSI; GUERRA, 2000).

De acordo com Cavalheiro (1996), no inicio da trajetória da Fonoaudiologia Educacional, sentiu-se uma certa resistência ou mesmo desconfiança por parte dos profissionais da escola, talvez por desconhecerem o fazer fonoaudiológico. Não havia uma rejeição dirigida à área, mas uma falta de identidade entre o fonoaudiólogo e o sistema educacional.

Sabemos explicitamente a proposta da Fonoaudiologia na escola. Sendo assim, surge uma incógnita, porque será que ainda continua tão difícil, a inserção efetiva do fonoaudiólogo nas escolas?

Hoje em dia, deparamos com inúmeras escolas, principalmente as públicas, porém, as particulares, também, sem um fonoaudiólogo contratado para trabalhar com os alunos, bem como junto aos professores. Tal fato ocorre devido ao custo que se tem quando se contrata este profissional, e algumas vezes, pela falta de conhecimento por parte da escola dos benefícios que este pode oferecer aos seus alunos, prevenindo assim, muitos dos problemas relacionados a leitura e escrita principalmente, bem como, a realização de encaminhamento para clínicas nos casos particulares.

É importante relembrar que a Fonoaudiologia Educacional tem papel único, de caráter profilático, o de proporcionar assessoria fonoaudiológica favorecendo para que a escola tornese um ambiente saudável e propício ao desenvolvimento das habilidades comunicativas a partir da conscientização de pais, professores e alunos sobre a saúde fonoaudiológica. Sob essa perspectiva, promover a saúde fonoaudiológica no âmbito escolar, focalizando questões relacionadas ao desenvolvimento da linguagem (oral e escrita), fala, audição, funções alimentares, voz e fluência (CAVALHEIRO, 1996).

Kyrrillos, Martins e Ferreia (1997), realizaram uma pesquisa com alunos de uma escola, onde foram realizadas triagens fonoaudiológicas no início do ano letivo e após a triagem, foram 
realizadas palestras de orientação aos pais, professores e atendimentos a grupos de crianças que apresentavam dificuldades semelhantes até o mês de outubro do mesmo ano; no mês de outubro, foram realizadas novas triagens do mesmo modo da realizada do início do ano, onde pode-se observar uma diminuição de $20 \%$ em relação a discriminação auditiva dos alunos, 5\% em relação a deglutição atípica, 20\% de diminuição quanto a troca surda/sonora na fala, 20\% quanto a omissões ou troca de grupo consonantal, tal pesquisa foi comparada no próximo ano mostrando uma diminuição ainda maior em todos os aspectos citados anteriormente.

\subsection{O processo de Comunicação Oral e Escrita}

\subsubsection{Linguagem}

De acordo com Ferreira (1995), linguagem é o uso da palavra articulada ou escrita como meio de expressão e de comunicação entre as pessoas. Também é definida como a forma de expressão própria de um indivíduo, grupo, classe, etc. Uma outra definição é que a linguagem é tudo que se serve para expressar idéias, sentimentos, modos de comportamento, etc.

Para diferenciar língua e linguagem, o autor acima, define língua como sendo todo sistema de signos que serve de meio de comunicação entre indivíduos que pode ser percebido pelos diversos órgãos dos sentidos, o que leva a distinguir-se uma língua visual, uma linguagem auditiva, uma linguagem tátil, etc.

A linguagem é um meio de comunicação inter-humana privilegiada, onde introduz o indivíduo na vida social, tornando-se está, a característica principal do homem. A função comunicativa é apenas um aspecto, dentre tantos que a linguagem apresenta, e nem sempre a comunicação é a função mais importante do seu próprio uso (LAUNAY; BOREALMAIZONNY, 1989). 
Segundo Zorzi (2003), a linguagem é um meio privilegiado para representar fatos e conhecimentos, do presente, passado ou futuro.

Para Vygotsky (1989), um claro entendimento das relações entre pensamento e língua é necessário para que se entenda o processo de desenvolvimento intelectual. Linguagem não é apenas uma expressão do conhecimento adquirido pela criança. Existe uma inter-relação fundamental entre pensamento e linguagem, um proporcionando recursos ao outro. Desta forma a linguagem tem um papel essencial na formação do pensamento e do caráter do indivíduo.

A linguagem é um claro exemplo de função superior do cérebro cujo desenvolvimento se sustenta, por um lado, uma estrutura anatomofuncional geneticamente determinada e, por outro, no estímulo verbal dado pelo meio (CASTAÑO, 2003).

\subsubsection{Comunicação}

Para Mendes (1994), a comunicação destaca-se como o principal instrumento para que a interação e a troca aconteçam, assim, o processo de cuidar, no seu sentido mais amplo, tenha espaço para acontecer; afinal, “os componentes da comunicação formam o clima e a nutrição para a compreensão”.

Sfez (1994) colocou que a comunicação é a mensagem que um sujeito emissor envia a um sujeito receptor através de um canal, cujo andamento e impacto sobre o receptor são sempre calculáveis.

Kreps (1995) afirmou que a comunicação humana acontece quando uma pessoa responde a uma mensagem, sendo esta qualquer símbolo ao qual alguém presta atenção e lhe atribui um significado no processo de comunicação. 
Para este mesmo autor, existem as mensagens internas, como aquelas que enviamos a nós mesmos, e as externas, aquelas às quais reagimos ao nosso entorno, incluindo as outras pessoas. Já os significados são imagens mentais que criamos para interpretar fenômenos e desenvolver entendimento. Os seres humanos utilizam as mensagens externas para comunicarse na vida organizacional. O mesmo autor informa que existem dois tipos de sistemas de mensagens externas, os verbais e os não verbais.

De acordo com Mesquita (1997), a comunicação humana é um fenômeno interindividual, interno-externo e individual-coletivo. É compreensível quando a codificação e a decodificação da linguagem simbólica ocorrem, e sensível quando a interpretação dos códigos possibilita inúmeras significações.

Comunicar es compreender al outro y compartir com él referentes, móviles y objetivos parcialmente comunes. Esto es muy visible em la vida profesional: las necesidades de comunicación (entre individuos, entre diferentes oficios o atividades, con los usários etc.) son enormes y multiformes. (Zarifian, 1999, p. 45)

De acordo com Pimenta, Lima e Francisco (2004), a comunicação é uma atividade humana que todos conhecem e praticam, mas que poucos conseguem definir satisfatoriamente. Devido a estar presente no nosso dia a dia, os atos de comunicação parecem tão naturais, que dispensam maiores explicações. Porém, trata-se de um campo vasto, onde se entrecruzam, no mesmo esforço de compreensão científica, diversas áreas do conhecimento, compondo uma visão multidisciplinar. Assim, a comunicação é, então, a própria prática cotidiana das relações sociais: conservar aparências e guardar distâncias; vestir a roupa da moda; adotar tal ou qual atitude em relação a esta ou àquela pessoa; falar num certo tom de voz e assim por diante. Isto quer dizer que as situações de comunicação são muitas e diversificadas, relatam os autores anteriormente citados.

De acordo com Stefanelli, Carvalho e Arantes (2005), a comunicação é um processo de compreender e compartilhar mensagens enviadas e recebidas, e estas, exercem influência no 
comportamento das pessoas envolvidas, confirmando o fato das pessoas estarem constantemente envolvidas por um campo interacional.

De acordo com Braga e Silva (2007) a comunicação é importante para nosso crescimento como seres humanos, faz parte de nossas experiências anteriores e também daquelas adquiridas a cada dia. Somos seres de relações e esta compreensão nos leva a buscar maiores entendimentos sobre conceitos, princípios e habilidades a serem adquiridas no processo comunicativo.

De acordo com Passadori (2008), a comunicação flui no momento que se fala e o outro pode compreender. Quando falamos com o outro, podemos assim aplicar nossas percepções e permitimos também que aconteça o processo de transformação.

\subsubsection{Tipos de Comunicação}

De acordo com Mesquita (1997), a comunicação humana é uma área de investigação e de estudos muito complexa, é tanto um fenômeno quanto uma função social e profissional. Para este mesmo autor, ela é processada através de dois níveis: o verbal e o não verbal, sendo que a comunicação não-verbal é a forma não discursiva que pode ser transmitida através do corpo, de objetos associados ao corpo e dos produtos da habilidade humana, sendo que investigações científicas têm evidenciado que a importância das palavras, em uma interação entre pessoas é apenas indireta.

Para Stefanelli (1993), a comunicação ocorre em todos os momentos da vida, e nem sempre de forma verbal. Esta tem como objetivo, ajudar outra pessoa, desenvolvendo relações interpessoais construtiva e é classificada em duas formas: a verbal e a não verbal, sendo que a primeira, acontece com o uso da linguagem escrita ou falada, já a não verbal, são as mensagens enviadas ou recebidas por meio de gestos, posturas do corpo, expressões faciais, timbre de voz, 
significando assim que todas as mensagens que passamos, sendo ela verbal, ou não, tem um significado para a outra pessoa.

Para este mesmo autor, na maioria das comunicações, encontramos as duas formas, entretanto, devemos ressaltar, que muitas vezes não é necessário a realização de uma comunicação verbal, para compreender o que o outro está pensando.

De acordo com Takahashi e Pereira (1991), a comunicação tem “função vital, por meio da qual indivíduos e organização se relacionam uns com os outros, bem como o meio ambiente e com as próprias partes do seu próprio grupo, influenciando-se mutuamente e transformando fatos em informação”(p.128).

Para Freire (1983), a comunicação está no centro do processo do pensamento: “todo ato de pensar exige um sujeito que pensa, um objeto pensado, que mediatiza o primeiro sujeito do segundo, e a comunicação entre ambos, que se dá através de signos lingüísticos”. Relata ainda que “o mundo humano é, desta forma, um mundo de comunicação”. Na comunicação verbal, a linguagem oral, é a mais elaborada e a mais simbólica capacidade cognitiva do ser humano, representa, verifica e conhece como se organizam os eventos, fatos e experiências de toda e qualquer natureza humana.

De acordo com Silva (2006), pode-se afirmar que o indivíduo participa simultaneamente de duas dimensões existentes decorrentes de dois modos de se relacionar com o mundo: uma verbal que lhe confere um repertório psicolingüístico, proporcionando uma exteriorização do ser social e outra não-verbal que lhe confere um estatuto psicobiológico, proporcionando uma exteriorização do ser psicológico.

Quando se fala da comunicação não-verbal, Rector e Trinta (1985), relatam que o termo não-verbal por ser abrangente e pela oposição que faz ao componente verbal da comunicação humana. 
Mesquita (1997) afirmou que todos os indivíduos têm capacidade de emitir e receber sinais não-verbais, porém esta capacidade sofre influência da atuação profissional quanto da vida diária.

De acordo com Corraze (1982), a comunicação não-verbal é um meio, dentre outros, de transmitir informação; o autor se refere a este tipo de comunicação como "as comunicações não-verbais”. Neste tipo de comunicação são definidos os diferentes meios existentes de comunicação entre seres vivos que não utilizam a linguagem escrita, falada ou mesmo seus derivados, chamados, não-sonoros, como por exemplo a linguagem utilizada pelos surdos e mudos. Este tipo de comunicação abrange um extenso campo de comunicações, não restringindo apenas à espécie humana. Podemos encontrar este tipo de comunicação na dança das abelhas, o ruído dos golfinhos, a expressividade das artes, como: dança, música, teatro, pintura, escultura etc.

Este mesmo autor informou também que para o ser humano, as comunicações nãoverbais se processam através de três suportes, sendo o primeiro, o corpo, nas suas qualidades físicas, fisiológicas e nos seus movimentos; o segundo, no homem, ou seja, objetos associados ao corpo. Já o terceiro suporte refere-se a dispersão dos indivíduos no espaço (desde o espaço físico que cerca o corpo até o espaço territorial).

Para Knapp (1982), a comunicação não-verbal é dividida em sete áreas, são elas: a) movimento corporal ou cinésica (emblemas, ilustradores, expressões de afeto, reguladores e adaptadores); b) características físicas; c) comportamentos táteis; d) paralinguagem (qualidades vocais e vocalização); e) proxêmica; f) artefatos e g) o meio ambiente.

Segundo Davis (1979), a espécie humana, antes da evolução da linguagem, comunicavase através do corpo, gestos, que eram os meios que dispunham para a compreensão mútua, ou seja, a comunicação efetuava-se através da comunicação não-verbais. Porém, em decorrência 
do processo evolutivo, elaborou-se e dominou-se códigos, articulados entre si, que foram e são utilizados tanto para a comunicação oral quanto para a escrita, a chamada, comunicação verbal.

Segundo Lemos (2006), a comunicação não-verbal permeia toda a comunicação verbal e revela-se uma fonte importante de mensagens na comunicação organizacional. A comunicação não-verbal é uma fonte muito rica em mensagens que incide sobre a comunicação verbal.

A comunicação humana verbal e até mesmo não verbal, é o processo de transmitir a informações e compreensão de uma pessoa para outra. Sendo assim, se não houver compreensão, não ocorre a comunicação, completa o mesmo autor.

Para Stefanelli (1993), o diálogo é uma forma de comunicação verbal, no qual a apropriação da palavra é utilizada para transmitir uma mensagem, e mesmo expor suas idéias.

\subsubsection{Fala e Escrita}

Segundo Zorzi (2003), aprender a falar faz parte da nossa herança biológica, hereditária. O homem, independente da raça, cultura, sexo, cor, condições sociais, econômicas ou geográficas, nasce para falar, sendo essa uma característica universal da humanidade.

Segundo Fávero, Andrade e Aquino (2000), que a estrutura da fala se organiza em diferentes níveis:

-Local: onde a conversa se estabelece por meio de turnos através dos interlocutores, os quais se alternam e desenvolvem suas falas um após o outro, podendo haver momentos de hesitações, sobreposições e assalto ao turno.

-Global: onde deve-se respeitar o tópico discursivo.

Para Fávero, Andrade e Aquino (2000), quando falamos da escrita, trata-se um algo mais complexo do que a fala, onde para sua elaboração, como na fala, aborda-se um determinado assunto. A diferença dessas duas situações é que a construção do texto escrito, não diz respeito 
apenas ao conteúdo semântico, mas também a percepção das marcas de seu processo de produção, as quais orientam o interlocutor no momento da leitura de acordo com a aparição das pistas lingüísticas para a busca do leitor em relação a compreensão do texto, já na fala, esta vem acompanhadas de gestos, pausas, entonações etc.

Este mesmo autor relata que os textos, são formados por parágrafos, os quais, devem conter uma idéia principal. Diz também que nos textos bem formados, a cada parágrafo, deve relacionar-se uma idéia importante. Para a construção de um parágrafo na escrita, deve-se conter:

-Unidade: cada parágrafo deve conter uma idéia principal, onde idéias secundárias, devem estar interligadas com a principal.

-Coerência: Neste caso, o parágrafo deve ser bem elaborado de tal forma que fique claro ao leitor, qual é a idéia principal abordada.

-Concisão: o parágrafo deve conter a quantidade de informação adequada ao objetivo do texto.

Clareza: deve-se ter o cuidado de utilizar palavras adequadas ao contexto, para que o parágrafo se torne claro e sua leitura possa ser feita de madeira eficiente.

Fávero, Andrade e Aquino (2000), escrevem que nos casos da escrita, onde, no texto, necessita de mais parágrafos, a mudança de assunto não deve ser brusca, é necessário um encadeamento lógico e natural entre eles.

A escrita espontânea, observada durante o desenvolvimento de redações, necessita de que o escritor, apresente um bom conhecimento de linguagem interiormente, visto que uma vez que nesta situação não está presente nem o modelo visual e nem o auditivo, o que não acontece nas situações de cópias e ditados, respectivamente (LOFIEGO, 1995).

Para Luria (1981), a linguagem escrita é um instrumento essencial para o processo do pensamento, apresentando categorias verbais e orais. 
Segundo Vygotsky (1989), a escrita é uma função linguística distinta, que difere da fala oral tanto na estrutura quanto no funcionamento.

A importância da língua escrita é tão grande que é uma das metas prioritárias na escola, pois, levar o aluno a dominar a linguagem escrita, é dar-lhe possibilidade para que, por meio dela, ele possa alcançar conhecimentos, assim como se expressar (ZORZI, 2005).

A escrita não é uma habilidade que se desenvolve apenas no momento em que o indivíduo começa a freqüentar uma instituição, escolar, antes de chegar a "própria escrita”, a criança passa por diversas fases (ZUANETTI; CORRÊA-SCHNEK; MANFREDI, 2008).

De acordo com Lofiego (1995), a escrita é um código simbólico e não figurativo, diferenciado de acordo com as culturas, e é considerada um processo que envolve muita complexidade de codificação e decodificação, exclusivo do ser humano.

Segundo Sacaloski, Alavarsi e Guerra (2000), tanto a leitura quanto a escrita compõem algumas das formas mais aprimoradas da comunicação humana.

Para Francischini (1990), crianças cuja cultura familiar caracteriza-se pela transmissão de conhecimentos essencialmente pela oralidade, muito provavelmente, encontrarão dificuldades na aprendizagem de estratégias comuns à linguagem escrita.

A escrita é considerada uma expressão da linguagem oral, realizada por meio de sinais criados pelo próprio homem (SCHIAVONI, 2004).

Segundo Share (1995), a escrita é um sistema de representação da língua e não uma simples transposição gráfica da linguagem oral. A aprendizagem da linguagem escrita nos sistemas alfabéticos, como é o caso da língua portuguesa, depende da capacidade de processar a fala. Desta forma, para Salgado e Capellini (2004), linguagem oral e linguagem escrita estão intrínsicamente relacionadas.

Segue abaixo um esquema elaborado por Koch (1997), para salientar as principais diferenças entre fala e escrita apontadas na literatura. 
Tabela 2: Principais diferenças entre fala e escrita

\begin{tabular}{|c|l|}
\hline \multicolumn{1}{|c|}{ Fala } & \multicolumn{1}{c|}{ Escrita } \\
\hline Contextualizada & Descontextualizada \\
\hline Implícita & Explícita \\
\hline Redundante & Condensada \\
\hline Não planejada & Planejada \\
\hline $\begin{array}{c}\text { Predominância do "modus } \\
\text { pragmático" }\end{array}$ & $\begin{array}{c}\text { Predominância do "modus } \\
\text { intático" }\end{array}$ \\
\hline Fragmentada & Não-fragmentada \\
\hline Incompleta & Completa \\
\hline Pouco elaborada & Elaborada \\
\hline Pouca densidade informacional & Densidade informacional \\
\hline $\begin{array}{c}\text { Predominância de frases curta, } \\
\text { simples coordenadas }\end{array}$ & $\begin{array}{c}\text { Predominância de frases } \\
\text { complexas com subordinação abundante }\end{array}$ \\
\hline Pequena freqüência de passiva & Emprego freqüente de passiva \\
\hline Poucas nominalizações & Abundancia de nominalizações \\
\hline Menor densidade lexical & Maior densidade lexical \\
\hline
\end{tabular}

\subsubsection{O Processo de Aquisição da Escrita}

De acordo com Abaurre (1990), a fase da aquisição da escrita inicia-se no momento em que o falante começa a perceber a diferença entre fala e escrita.

Vygotsky (1991), descreveu também que a escrita é ensinada (na maioria das escolas), como uma habilidade motora e não como uma atividade cultural complexa, e destaca ainda que a escrita deve ter significado para as crianças.

De acordo com Massini-Cagliari (2001), o ambiente sócio-cultural exerce influência sobre o desenvolvimento da linguagem. Este mesmo autor coloca que o aspecto social da linguagem não é visto apenas como um lugar de convenções, mas também de relações entre o indivíduo e a coletividade, de cultura, etc.

Para Lourdes e Matencio (1994), as atividades discursivas e as práticas sociais, às quais os sujeitos têm acesso durante o processo de sociabilização, têm influência direta sobre a 
construção dos sentidos, quer seja pela leitura, escrita ou fala. Estes mesmo autores, informam ainda que a escrita difere entre as comunidades.

Lyon (1999); Aswank (1999, apud ZORZI, 2003), relataram que para aprender a escrever, tem que ter aprendido inicialmente o sistema alfabético, onde é necessário que a criança compreenda que as letras correspondem a segmentos sonoros.

De acordo com Sacalosky, Alavarsi e Guerra (2000), a escrita é construída por meio de exposição a estímulos gráficos, geralmente por intermédio de um indivíduo adulto que pode ser um dos familiares ou o professor.

Os mesmos autores relataram que as produções escritas das crianças refletem um importante aspecto em termos de linguagem, que é o domínio do código gráfico, uma vez que implica em abstração e na ausência do interlocutor.

A escrita é um conhecimento que se constrói social e culturalmente num contexto interacional, assim o papel do adulto como mediador entre a criança e a escrita é importante. A aprendizagem da linguagem escrita, está vinculada à escolarização e as condições favoráveis que a escola apresenta para a aquisição da escrita (SMITH, 1982).

Para Chafe (1985), o processo de aquisição da escrita é considerado lento, o que favorece maior integração de uma sucessão de idéias em um todo coerente e unificado.

Para Zorzi (1999/2000), aprender a escrever implica em compreender características da língua escrita que fazem parte do sistema ortográfico.

Ferreiro e Teberosky (1986 apud ZORZI, 2003), dividiu a aquisição da linguagem escrita em 4 fases, sendo elas: Fase pré silábica, Fase silábica, Fase silábico-alfabética e Fase alfabética, as quais serão descritas abaixo.

Fase pré silábica: Nesta fase, a criança se encontra num processo construtivo e criativo. É nela que se começa a fazer a distinção entre desenhar e escrever. Como característica principal, 
temos a não distinção dos sons que compõem as palavras e os elementos gráficos usados para escrevê-las.

Fase silábica: Nesta fase a palavra falada, começa a ser escrita como unidades silábicas, definindo a quantidade de letra a serem utilizadas. Neste momento da aquisição, a criança utiliza para cada sílaba uma letra.

Fase silábico-alfabético: Nesta fase, a criança começa a perceber que as sílabas podem ser esmiuçadas em elementos menores, os quais são chamados de fonemas. Podemos perceber neste período que algumas sílabas já são representadas por mais de uma letra.

Fase alfabética: Neste momento, a criança compreende que a escrita das sílabas que compõem as palavras, nem sempre são representadas por uma só letra. É nesta fase que a criança passa a compreender que uma mesma letra, pode representar diversos sons.

\subsubsection{Construção de texto}

Para abordarmos o assunto construção textual, é necessário inicialmente definirmos o que é um texto.

De acordo com Brasil (2001), um texto é todo trecho falado ou escrito que constitui um todo unificado e coerente dentro de uma determinada situação discursiva. Sendo assim, texto não é sua extensão, mas sim, o fato de que é uma unidade de sentido em relação a uma situação.

De acordo com Koch e Travaglia (1990), texto é “uma unidade linguística concreta que é tomada pelos usuários da língua (falante, escritor/ ouvinte, leitor), em uma situação de interação comunicativa, como uma unidade de sentido e como preenchendo uma função comunicativa reconhecível, independentemente da sua extensão” 
Para Tannen (1982), o texto é muito mais do que uma simples seqüência de enunciados. Cada estilo de texto envolve conteúdo, função social, organização lingüística e componentes estruturais específicos que o definem e o diferenciam dos demais.

Para Gonçalves e Dias (2003), a comunicação entre usuários da língua não se estabelece através de frases isoladas, o homem se comunica por meio de textos e existem diversos fenômenos lingüísticos que só podem ser explicados no interior deste.

Para Koch (1998), um texto não é apenas uma seqüência de frases isoladas, mas sim, uma unidade lingüística com propriedades estruturais específicas.

A produção de um texto escrito depende de uma unidade, onde diversas partes se juntam e se articulam gerando assim um todo único, sendo que se faltar alguma parte, pode chegar a comprometer o sentido de sua mensagem. Desta maneira, alguns princípios e regras devem ser obedecidos para que o texto seja reconhecido totalmente (SAYEG-SIQUEIRA, 1990).

Podemos citar como características do texto a coesão, coerência, sintaxe, léxico, uso de pontuação e erros ortográficos.

Segue abaixo os aspectos os quais devem ser encontrados quando nos deparamos com a análise de textos. São eles:

\section{> Coesão}

De acordo com Gonçalves e Dias (2003), a textualidade é um fenômeno lingüístico que se constitui a partir da coerência e da coesão presentes nos textos veiculados nas práticas sociais as quais se encontram inseridos. Neste sentido, faz-se necessário uma apresentação de algumas concepções teóricas sobre a Lingüística de Textos, que revelam as relações existentes entre a coesão e coerência textual.

Halliday e Hasan (1976) consideraram que a coesão tanto pode ser gramatical como lexical, no entanto, apenas os mecanismos de coesão não fariam do texto um texto. Eles 
afirmam que o texto necessita ter coerência para estabelecer o envolvimento dos vários componentes interpessoais, sendo assim a coesão algo interno (lingüística) e a coerência, algo externo, pois diz respeito aos contextos de situação.

Segundo Widdowson (1978), coesão é o processo pelo qual as frases ou partes delas são conectadas entre si para garantir o desenvolvimento proposicional, ou seja, a coesão esta ligada aos aspectos gramaticais.

De acordo com Cagliari (2001), os mecanismos de coesão são todos aqueles elementos do texto que fazem referência a outros elementos do texto.

Araújo (1997) em sua análise quanto a elementos de ligação, concluiu que “a ligação entre as palavras ocorra com diferenças graduais, ou seja, a palavra na oração, a oração no período, o período no parágrafo, o parágrafo no texto”.

Fávero (1991) definiu coesão como sendo o modo como os componentes contidos em um texto estão ligados entre si dentro de uma seqüência.

\section{$>$ Coerência}

Para Widdowson (1978), a coerência está diretamente ligada ao desenvolvimento dos atos ilocucionais, por meio das proposições, possibilitando a dedução das ligações proposicionais implícitas, a partir de uma interpretação dos atos ilocucionais.

A coerência dá textura à seqüência lingüística, entendendo-se por textura aquilo que converte uma seqüência lingüística em texto, assim a seqüência é percebida como texto quando aquele que o lê, consegue compreende-lo como um todo. É uma continuidade de sentidos perceptíveis no texto, dando condições de criar um mundo textual de acordo com os conhecimentos de mundo encontrados na memória do leitor (KOCH; TRAVAGLIA, 1999).

Levando em consideração os dados trazidos por Gonçalves e Dias (2003), a coerência abrange, além da coesão textual, outros fatores, como os elementos lingüísticos, conhecimento 
de mundo, conhecimento partilhado, informatividade, intertextualidade, intencionalidade e aceitabilidade.

Os autores Koch e Travaglia (1999) dão ênfase à relação estabelecida entre os aspectos lingüístico, conceitual-cognitivo (conhecimento de mundo) e pragmático, reforçando cada vez mais a importância das marcas lingüísticas como pistas à construção do sentido e, portanto, da coerência do texto.

Para os mesmo autores acima citados, a coerência está diretamente ligada à possibilidade de se estabelecer um sentido para o texto, isto significa que ela é o que faz o texto ter ou não sentido.

\section{>Estrutura Sintática}

Rego e Buarque (1997), informaram que o desenvolvimento da consciência sintática facilita a aquisição das regras ortográficas que envolveram análises morfossintáticas. Este estudo foi realizado com 46 crianças brasileiras de classe baixa, onde estas foram avaliadas quando ao desenvolvimento da consciência metalingüística no início da primeira série e quanto à aquisição da ortografia no final da primeira e da segunda série. Os resultados obtidos, indicaram que a consciência sintática é um facilitador específico fonológico contribui principalmente para a aquisição de regras de contexto grafofônico.

Francischini (1990) referiu que o processo de produção da escrita é lento o que permite maior integração de uma sucessão de idéias em um todo lingüístico coerente e unificado.

\section{$>$ Léxico}

Estudos realizados por Abaurre e Silva (1993) já haviam demonstrado que as crianças pequenas não utilizam critérios morfológicos convencionais de segmentação da linguagem, 
tendendo a dividir a oração em unidades semânticas ou sintáticas, destacando os substantivos ou separando a oração em sujeito e predicado.

Segundo Halliday (1989), a linguagem falada é mais dispersa, mais complexa sintaticamente, ao passo que a linguagem escrita é mais condensada, pois nela há maior densidade lexical

Benedict (1979) escreveu que existem dois grandes fatores que contribuem para o desenvolvimento lexical nos primeiros anos de vida da criança: o imput lingüístico dos pais e as habilidades cognitivas da criança. Este concluiu que os pais participam da aquisição de novos vocábulos pelas crianças e as influenciam na escolha da palavra.

\section{> Uso de pontuação}

De acordo com Gumperz et al. (1984), durante a fala podemos utilizar pausas, gestos, entre outros recursos paralinguísticos, já a escrita, não nos permite essas utilizações. Para um leitor compreender a escrita, é necessário que o escritor, faça uso adequado da pontuação em todo o texto, para que ao ler, o leitor, compreenda todo o conteúdo.

Caldana (2002), relatou em sua tese de doutorado, que no que diz respeito a linguagem e ao uso de sinais, pode-se observar que não acontece apenas uma substituição da fala para a escrita, “mais sim da incorporação dos aspectos comunicativos.” (p.44)

A linguagem escrita possui estrutura e convenções próprias, uma delas é a pontuação (Kress, 1982).

Paschoalin e Spadoto (2000) informaram que “os sinais de pontuação são recursos típicos da língua escrita porque esta não dispõe do ritmo e da melodia da língua falada. A pontuação é um meio de representar, na escrita, as pausas e entoações da fala. Sendo assim, não há critérios extremamente rígidos quanto ao uso dos sinais de pontuação”. 


\section{>Erros Ortográficos}

Zorzi (1998), elaborou alguns parâmetros para analisar a escrita em relação aos possíveis erros ortográficos que poderiam aparecer na escrita de alunos de quatro primeiras séries do Ensino Fundamental, em escolas particulares na cidade de São Paulo.

São eles:

-Representações Múltiplas: quando um mesmo som pode ser escrito por várias letras ou uma mesma letra pode representar diferentes sons. Exemplos: o fonema /s/ pode ser representado por uma diversidade de letras como s, ss, ç, c; caçador, casador; sentido-centido.

-Apoio na oralidade: Palavras grafadas erroneamente em virtude de um apoio no modo de falar para decidir o modo de escrita, havendo uma discrepância entre os mesmos. Exemplos: trabalhar, trabaiar; dormir - dormi.

-Omissões de letras: quando palavras grafadas de modo incompleto, em função da omissão de uma ou mais letras. Exemplos: sangue - sague; comprou-compou.

-Junção ou separação não convencional das palavras: problemas quando a segmentação resulta em palavras unidas entre si ou fracionadas em um menor número de sílabas do que deveriam ter. Exemplo: às vezes -asvezes; naquele - na quele.

-Confusão entre as terminações am e ao: palavras que terminam com am e que são grafadas com ao, e vice-versa. Exemplos: começaram - começarão; saíram - sairão.

-Generalização de regras: alterações decorrentes e formas de grafar palavras que parecem reveladoras do modo como as crianças generalizam certos procedimentos de escrita, porém aplicando-os a situações nem sempre apropriadas. Exemplo: fugiu - fugio; emagreceu emagresel.

-Substituição da grafia de fonemas surdos e sonoros: alterações de escrita dizendo respeito a determinadas substituições de grupos de letras que apresentam em comum o fato de 
representarem fonemas que se diferenciam pelo traço de sonoridade. Exemplos: pegando peganto; perdido - perdito.

-Acréscimos de letras: aumento ou acréscimo de letras na palavra escrita. Exemplos: machucar - manchucar; apareceu - papareceu.

-Letras parecidas: palavras escritas erroneamente em razão do uso de letras incorretas, mas cuja grafia apresenta algumas semelhanças com a letra que deveria ser utilizada. Exemplos: tinha - timha; caminho - caminlo.

-Inversão de letras: palavras apresentando letras em posição invertida no interior da sílaba, ou mesmo em posição distinta daquela que deveria ocupar dentro da palavra. Exemplo: acabou - arcodou; enxugar - enxugra.

-Outras: Alterações observadas em uma ou outra criança em particular, parecendo estar restrita à sua forma de escrever, isto é, seus erros ou enganos não eram partilhados de uma forma mais freqüente ou geral como as categorias anteriores.

\subsubsection{Leitura}

Podemos encontrar no dicionário Ferreira (1995), a seguinte definição: “ato ou efeito de ler, arte de ler, hábito de ler, aquilo que se lê, o que se lê considerando em conjunto, arte de decifrar e fixar um texto de um autor, segundo determinado critério”.

O acesso ao aprendizado da leitura apresenta-se como um dos múltiplos desafios existentes na escola e, quem sabe, o mais valorizado e exigido pela sociedade. De acordo com a afirmação de Foucambert (1994), o acesso à escrita é o único meio de alcance da democracia e do poder individual, o qual é definido por ele como "a capacidade de compreender por que as coisas são como são" (p.123). 
Este mesmo autor informou também que hoje em dia, as escolas continuam pretendendo atingir o objetivo de alfabetização com o propósito de favorecer o acesso dos alunos as técnicas de leitura e escrita, com vistas ao aperfeiçoamento em massa desta ferramenta de produção para atender às exigências do desenvolvimento do mundo do trabalho.

Ferreira e Dias (2002), relataram em seu trabalho a relevância da escrita como um fator possibilitador do desenvolvimento cognitivo do indivíduo e da sua inserção social nas sociedades letradas. Comentaram também que a leitura tem sido muito discutida por pesquisadores e educadores, onde quando o assunto é o papel do ensino da leitura e da escrita destaca-se, que é na escola que o contato com o sistema de escrita ocorre de forma sistematizada.

Foucambert (1994) acreditou que a leitura é uma atividade para os olhos e não para os ouvidos, querendo dizer com isto que a leitura não se restringe ao aprendizado das correspondências letra-som, mas que o extrapola.

\subsubsection{Aprimoramento da Comunicação}

Levando em consideração que o ambiente competitivo na economia globalizada encontrado hoje em dia tem exigido das empresas um novo posicionamento estratégico centrado no conhecimento, afeta não só os processos produtivos, mas principalmente o processo de gerenciamento de pessoas. Assim, se vê a necessidade das empresas gerirem seus ativos do conhecimento, na forma de eliminar barreiras significativas à comunicação. $\mathrm{O}$ sucesso ou o fracasso do compartilhamento do conhecimento está na responsabilidade e competência gerencial de cada empresa (Pimenta, Lima e Franscisco, 2004).

Levado os dados acima em consideração, Pimenta, Lima e Franscisco (2004) informaram que com isso, as empresas que se identificam com esta realidade do mercado global, estão 
buscando intensamente estratégias de ação considerando a qualidade, produtividade e, principalmente, de competitividade. Assim, com o crescimento da competitividade, as empresas passam a ser reconhecidas por sua nova postura. Para isto, uma das competências requeridas do gerente de empresas, que é também a base da vantagem competitiva, é a comunicação eficaz.

De acordo com Nascimento et al., (1999), a comunicação eficaz é reconhecidamente uma das características fundamentais de organizações competitivas.

Os mesmo autores relataram que quando se fala em aprimoramento da comunicação, vêm em mente também as palavras, melhorar, trabalhar algo. Assim, quando tratamos de alunos, percebemos que estes têm a necessidade de serem ouvidos e de estabelecerem uma relação com o professor, ou até mesmo com algum outro profissional o qual freqüenta a sala de aula, pois estes, transmitem novos conteúdos a estes alunos.

Na adolescência, o professor pode auxiliar esse jovem por meio de uma comunicação adequada e mesmo esclarecer dúvidas e dificuldades. Uma das ferramentas também que podem ser utilizadas nesta relação professor-aluno-profissional, é a comunicação, que se constitui um comportamento essencial nas relações interpessoais, que tem como finalidade a troca de experiências entre as pessoas, compreender como elas vivenciam o seu mundo e até mesmo ajudar na resolução dos problemas específicos de cada um (STEFANELLI, 2005).

De acordo com Stefanelli (2005) é de competência do profissional da saúde usar o conhecimento sobre a comunicação humana para ajudar o outro a descobrir e utilizar sua capacidade e potencial para solucionar conflitos, reconhecer suas limitações pessoais, ajustar-se ao que não pode ser mudado e a enfrentar os desafios a auto-realização, procurando aprender a viver da forma mais saudável possível, tendo como meta encontrar um sentido para viver com autonomia. 


\section{PROPOSIÇÃO}

O presente estudo teve como objetivo geral, implantar uma Oficina de Aprimoramento da comunicação escrita para jovens que buscam o Primeiro Emprego, e como objetivos específicos:

1) Caracterizar a amostra de adolescentes quanto aos conhecimentos sobre a comunicação oral e escrita;

2) Caracterizar as alterações fonoaudiológicas de adolescentes que freqüentam a Diocese de Bauru Divino Espírito Santo (Casa do Garoto Rogacionista) na cidade de Bauru-SP.

3) Elaborar e aplicar uma Oficina de trabalho com esses adolescentes para aprimorar suas habilidades comunicativas no que diz respeito à linguagem escrita.

4) Verificar se houveram mudanças em relação a escrita dos alunos após as Oficinas de Aprimoramento da Comunicação realizadas.

5) Verificar a percepção dos adolescentes sobre o programa 


\section{MATERIAL E MÉTODO}

Este projeto teve seu início após aprovação do Comitê de Ética em Pesquisa da Faculdade de Odontologia de Bauru (FOB-USP), de acordo com a resolução n 196/96 do Conselho Nacional do Ministério da Saúde. Número do Protocolo de aprovação do Comitê de Ética: 91/2007, data: 27/06/2007.

\subsection{Local da coleta dos dados}

A coleta da pesquisa foi realizada nas dependências da Instituição nomeada como "Casa do Garoto” na cidade de Bauru-SP.

A Casa do Garoto é uma Entidade Filantrópica destinada aos atendimentos de pessoas de baixa renda, em vulnerabilidade e/ou situação de risco, fundada na cidade de Bauru no dia 25 de dezembro de 1949. Os Rogacionistas assumiram a obra sócio-educativa em 18 de agosto de 1.951, para dar continuidade a Obra Rogacionista fundada por Santo Aníbal Maria di Francia, que iniciou a obra na Itália e cujo ideal era o atendimento a crianças, adolescentes e famílias carentes. Sua obra espalhou-se por todo o mundo, com obras sociais em muitos lugares, são elas: Programas Sócios Educativos, atendimento a jovens, idosos, creches, orfanatos, casa abrigo, casa de passagens, etc.

A Entidade atua no atendimento a crianças e adolescentes de 7 a 14 anos, além de jovens de 15 a18 anos, assim como suas famílias. Em parceria com a Prefeitura Municipal de Bauru/ Secretaria do Bem Estar Social (SEBES) e Governo do Estado, oferecem os seguintes programas: 
- CCIJ: Centro de Convivência Infanto-Juvenil - Dirigido a 266 inscritos de 7 a 14 anos. Eles recebem alimentação e desenvolvem atividades complementares às escolas de apoio pedagógico, oficinas de arte, cultura, lazer e espiritualidade. Recebem alimentação e demais benefícios da Entidade.

- Preparação para o Primeiro Emprego - Então inscritos 60 adolescentes de 15 a 17 anos e 11 meses, visando formação em desenvolvimento pessoal, informática e cursos administrativos para inserção no mercado de trabalho. Recebem alimentação e demais benefícios da Entidade.

- Preparação para o Trabalho e Renda - Panificação - Para 50 inscritos a partir de 16 anos - da Comunidade em geral na linha sócio assistencial - Terças e quintas feiras de manhã e a tarde.

- Lar Social Santo Aníbal - Trabalha com 20 adolescentes de 12 a 17 anos e 11 meses, em situação de abandono ou risco familiar, encaminhados pela autoridade judiciária ou Conselho Tutelar. Em situação semelhante e processo de implantação, desenvolvimento e Projeto República Jovem para 6 jovens que já completaram 18 anos, para trabalhar a emancipação e a inserção desse jovem à sociedade.

Além dos programas acima, a Casa do Garoto passou a oferecer a partir de agosto de 2008 o "Pró-Jovem" destinado a jovens de 15 a 17 anos e 11 meses, com 100 vagas. De responsabilidade do Ministério do Desenvolvimento Social em parceria com a Prefeitura Municipal de Bauru/ Secretaria do Bem Estar Social (SEBES) e Entidades Sociais. No projeto são realizadas atividades culturais, esportivas, lazer e temas transversais para o desenvolvimento da cidadania, em dois núcleos de atendimento: 1) Núcleo da Casa do garoto Parque Vista Alegre, 2) Núcleo Capela São Pedro - Jardim Godoy. 
Além dos Projetos mantidos pela Prefeitura e o Estado desenvolvem ainda o Informática Solidária com 30 vagas em parceria com o Cáritas Diocesana (Fundo de Solidariedade) destinadas a Comunidade em geral para pessoas com idade a partir de 16 anos.

Para manutenção de todos os programas oferecidos, a Instituição consta de subvenções municipais e estaduais, também com a colaboração de toda a sociedade bauruense na participação de eventos, doações de produtos, trabalhos voluntários, e também com a parceria da Pastoral de Promoção Humana e demais Pastorais da Paróquia Nossa senhora das Graças.

Para a realização da pesquisa, foi cedida pela diretora uma sala de aula onde foram realizadas as triagens, individualmente com cada aluno. Os encontros para a realização as Oficinas foram realizados em duas salas: Sala de Psicologia e Sala de Informática, esta variação acontecia, de acordo com o local onde a Turma da manhã e Turma da tarde (A ou B) estavam no dia do atendimento.

\subsection{Seleção dos Sujeitos}

Os sujeitos da amostra tinham como critério obrigatório serem alunos provenientes do programa "Primeiro Emprego" oferecido pela entidade “Casa do Garoto Rogacionista” localizada no município de Bauru/SP, terem idade entre 15 e 18 anos, independentemente de gênero. O único critério de exclusão foi a não assinatura do responsável no Termo de Consentimento Livre e Esclarecido.

Os adolescentes foram selecionados a partir de uma relação fornecida pela Assistente Social da "Casa do Garoto Rogacionista”, a qual relatava os nomes dos participantes deste Programa. 
De uma relação inicial de 60 alunos do Programa “Primeiro Emprego" em Março de 2008 na “Casa do garoto”, 50 passaram pelos critérios de inclusão e assinaram o TCLED, os outros 10 desistiram do programa antes do início desta pesquisa. Durante o desenvolvimento da pesquisa outros 20 alunos abandonaram o programa, sendo excluídos da pesquisa. Sendo assim, o trabalho foi realizado com 30 alunos. Os alunos freqüentadores do "Primeiro Emprego", foram divididos pela instituição por períodos, de acordo com a disponibilidade deles em freqüentar o curso, turma da manhã (5 alunos) e turma da tarde (25 alunos), sendo que a turma da tarde, devido ser composta por um número maior de alunos, houve a necessidade de ser dividida em 2 grupos, nomeados pela instituição de Grupo A (10 alunos) e Grupo B (15 alunos). Todos os grupos eram compostos por alunos do sexo masculino e feminino, não havendo separação destes.

\subsection{Procedimentos e Materiais da Coleta}

Inicialmente foi realizado o primeiro contato com a Diretora da Instituição, onde foi entregue uma cópia do Projeto de Pesquisa, que continham informações sobre qual seria o trabalho realizado com o público alvo, no caso, os adolescentes freqüentadores do Programa Primeiro Emprego da Casa do Garoto. Tento o consentimento da Diretora, a qual também é assistente social, deu-se início ao andamento do Projeto.

No primeiro contato com os adolescentes, foi informado o objetivo da pesquisa e a duração média do programa que seria oferecido a eles, bem como solicitado que seus responsáveis assinassem o Termo de Consentimento Livre e Esclarecido (TCLE) após uma explicação detalhada sobre a proposta do trabalho. Também foram esclarecidos acerca da natureza confidencial dos dados no caso de divulgação dos resultados e de depoimentos. 
Após o contato inicial, a pesquisadora chamou cada aluno individualmente em uma sala fornecida pela Diretora para a realização das triagens. Para a realização desta, a Fonoaudióloga instruiu cada aluno sobre o que seria avaliado, bem como caso houvesse algum tipo de alteração as quais não seriam trabalhados nas Oficinas posteriormente oferecidos, estes alunos seriam encaminhados para a Clínica de Fonoaudiologia ou Odontologia, da Universidade de Bauru. FOB-USP, se necessário.

As triagens avaliaram os seguintes aspectos fonoaudiológicos: Motricidade Oral, Voz, Linguagem Oral e Gráfica. Para a avaliação, a pesquisadora utilizou um protocolo, o qual constava de uma ficha de identificação referente a dados pessoais dos sujeitos seguidas de questões referentes à avaliação fonoaudiológica (Apêndice A). O tempo médio da triagem com cada adolescente era de 25 minutos, e os encontros para a realização destas eram em 1 vez por semana (segunda, terça ou quarta-feira, respeitando a preferência das professoras para não atrapalhar o andamento das aulas), com as 3 turmas, sempre no horário que os alunos estavam na Instituição e o período em que eles estudavam (manhã ou tarde).

Após a triagem, os alunos responderam um questionário individualmente, sobre alguns aspectos relacionados aos seus conhecimentos e percepções sobre suas habilidades comunicativas (Apêndice B).

Posteriormente, após ter os dados obtidos na triagem, foi proposto uma Oficina de Aprimoramento da Comunicação, considerando as alterações encontradas quanto Escrita dos adolescentes, já que foram encontrados dados em literatura, que adolescentes de classe social desfavorável, apresentam dificuldades escolares, principalmente quando a este aspecto, e esta, foi avaliada na triagem da seguinte forma: era oferecido uma folha em branco ao aluno e solicitado que escrevesse as palavras, frases e textos ditados à ele, e em seguida para avaliar a escrita espontânea, foi solicitado que o adolescente escrevesse o que ele quisesse, porém respeitando o tema “Quem sou eu” fornecido pela pesquisadora. 
Estas Oficinas constavam de estratégias diretamente ligadas às dificuldades apresentadas pelos adolescentes, na forma de um programa preventivo-educativo, e foram pretendidos inicialmente encontros 1 vez por semana durante 8 semanas, (mês de junho e mês de agosto de 2008), com duração de 1 hora com cada turma, lembrando que existia 1 turma no período da manhã e 2 turmas (A e B) no período da tarde, sendo estes, realizados sem nenhuma intercorrência ou mudança de datas, totalizando semanalmente 3 horas de oficinas, e 24 horas de Oficinas totais, sendo que com cada turma, 8 horas.

Segue abaixo os assuntos que foram abordados nas Oficinas de Aprimoramento da Comunicação e Escrita com os adolescentes:

-Leitura e sua importância

-A concepção de texto

-A coesão

-A coerência

-Aspecto semântico

-Estrutura sintática

-Léxico

-Erros ortográficos

-Uso adequado da pontuação

- Relação oralidade X escrita

Os assuntos acima foram abordados da seguinte forma:

Inicialmente houve a necessidade da Fonoaudióloga esclarecer o motivo dos assuntos que seriam oferecidos nas Oficinas, onde foram explicados através de uma conversa, os dados coletados na triagem, algumas literaturas lidas pela pesquisadora, fazendo sempre a relação das 
dificuldades que as escolas públicas em nosso país enfrentam e as conseqüências destas dificuldades, resultando assim, em alunos com algum tipo de alteração na sua comunicação, sendo a principal alteração a Escrita. Assim, viu-se necessário abordar os assuntos citados acima, para esclarecer, bem como melhorar a escrita destes adolescentes.

Após a explicação, deu-se início as atividades oferecidas pelas oficinas.

Todos os encontros foram realizados da seguinte forma:

Inicialmente, a Fonoaudióloga, dizia qual seria o assunto abordado na Oficina, em seguida, era questionado se algum aluno sabia qual era o significado da palavra abordada, e assim iniciavam as atividades. Na primeira parte do encontro, era solicitado, que cada aluno lesse um pedaço do roteiro explicativo entregue a todos alunos, impressos em folha de papel sulfite. Neste momento, caso houvesse dúvida de alguma palavra por parte dos alunos, eram oferecido um dicionário, onde o aluno com duvida deveria procurar a palavra, e então ler em voz alta para toda a sala o significado, tirando assim dúvida de outras pessoas também.

Após cada parágrafo lido, a Fonoaudióloga, explicava o assunto, sempre oferecendo exemplos simples e fáceis para a compreensão dos adolescentes.

Após a leitura de todo o folheto explicativo, era questionado aos alunos se restaram dúvidas ou se algum assunto não foi bem esclarecido, e se sim, a Fonoaudióloga tentava por meio de outros exemplos e outras palavras tirar as dúvidas.

Após todo o assunto esclarecido, era proposto uma situações de escrita, onde o aluno deveria escrever um texto com temas decididos durante a oficina, lembrando sempre do conteúdo abordado no dia. O texto era escrito individualmente e entregue para a Pesquisadora no final do período. Esses textos eram lidos em voz alta pela Fonoaudióloga e discutido com os alunos, em relação à forma em que estava escrito, se tinha ou não utilizado durante a escrita os conhecimentos adquiridos na Oficina. 
Após as oficinas, os textos coletados ficavam com a Pesquisadora, os quais eram anexados junto às fichas de identificação de cada aluno para melhor organização do trabalho.

Todos os alunos inseridos no programa participaram das Oficinas oferecidas. Os adolescentes que durante a triagem, apresentaram alterações consideradas significativas, foram encaminhados para a Clínica de Fonoaudiologia da Faculdade de Odontologia de Bauru (FOBUSP) para atendimento terapêutico, sendo estes inseridos na fila de espera para o atendimento.

Após o término da aplicação das Oficinas realizadas, foram feitas novas coletas da amostras das escritas dos alunos (ditado de palavras, frases e texto, e da escrita espontânea, Apêndice L), utilizando a parte do Protocolo de Triagem Fonoaudiológica (Apêndice A), com o intuito de constatar a eficiência ou não da Oficina de Aprimoramento da Comunicação.

Na fase final, a pesquisadora aplicou outro questionário individualmente (Apêndice C) para investigação da percepção dos adolescentes em relação ao programa.

\subsection{Procedimento de Analise dos dados}

O critério de análise fonoaudiológica foi verificar se a escrita do adolescente estava adequada ou não, considerando a idade que ele tem e o nível escolar em que este se encontra, considerando assim que todos adolescentes, apresentando idade de 15 a 18 anos, freqüentadores de séries $7^{\circ}$., $8^{\circ} .9^{\circ}$ ano do Ensino Fundamental, e também do Ensino Médio, devem apresentar um domínio pleno da escrita.

Já a ortografia foi avaliada de acordo com os critérios de Zorzi (1998) mencionado na revisão de literatura do presente trabalho.

Para a análise dos dados coletados neste trabalho, os resultados foram descritos em tabelas com uso de freqüência absoluta (n) e relativa (\%) para uma melhor visualização do leitor. 
Tendo como objetivo deste trabalho, implantar uma Oficina de Aprimoramento da Comunicação e escrita para os jovens que buscam o "Primeiro Emprego", foi necessário avaliar a escrita inicial, realizar um aprimoramento da comunicação oral e escrita e em seguida reavaliar a escrita dos alunos. Para esta analise, foi utilizado o teste de McNemar para a comparação dos dados iniciais, com os dados finais da escrita. Este teste proporciona uma comparação, onde se tem o resultado se houve mudanças estaticamente significativas ou não.

Em relação a comparação entre o número de parágrafos na avaliação inicial com a final da escrita foi utilizado o teste “t” pareado.

Em todos os testes estatísticos foi adotado nível de significância de 5\% ( $<<0,05)$. 


\section{RESULTADOS}

Para uma melhor compreensão do leitor deste estudo, os resultados, serão apresentados em 5 partes, de acordo com os questionários aplicados, oficina realizada, bem como analise da escrita dos alunos participantes. São elas:

Etapa I - Aplicação do Protocolo de Triagem Fonoaudiológica (Apêndice A) e análise da escrita inicial

Etapa II - Aplicação do Questionário Inicial (Apêndice B) e análise deste

Etapa III - Realização das Oficinas de Aprimoramento da Comunicação Escrita

Etapa IV - Coleta da Escrita final e Análise da comparação entre a escrita inicial e escrita final)

Etapa V - Aplicação do Questionário Final (Apêndice C) e análise deste

\section{ETAPA I}

Aplicação do Protocolo de Triagem Fonoaudiológica (Apêndice A) e análise da escrita inicial

Tabela-3: Idade dos sujeitos

\begin{tabular}{ccc}
\hline Idade & $\mathrm{n}$ & $\%$ \\
\hline 15 & 21 & 70,0 \\
16 & 6 & 20,0 \\
17 & 1 & 3,3 \\
18 & 2 & 6,7 \\
\hline Total & 30 & 100,0 \\
\hline
\end{tabular}


Tabela-4: Escolaridade dos sujeitos

\begin{tabular}{ccc}
\hline Escolaridade & $\mathrm{n}$ & $\%$ \\
\hline $7 \mathrm{EF}$ & 1 & 3,3 \\
$8 \mathrm{EF}$ & 1 & 3,3 \\
$9 \mathrm{EF}$ & 2 & 6,7 \\
$1 \mathrm{EM}$ & 18 & 60,0 \\
$2 \mathrm{EM}$ & 7 & 23,3 \\
3 EM & 1 & 3,3 \\
\hline Total & 30 & 100,0 \\
\hline $\begin{array}{l}\text { EM- Ensino Médio } \\
\text { EF- Ensino Fundamental }\end{array}$ & &
\end{tabular}

Em relação as manifestações fonoaudiológica notamos que 24 (80\%) não apresentaram alterações fonéticas, porém 6 (20\%), sim.

Os tipos de alterações fonéticas foram: 2 (6,6\%) apresentaram a alteração do tipo distorção do fonema /s/, 2 (6,6\%) apresentaram distorção dos fonemas /s/ e /z/, 1 (3,3\%) com distorção dos fonemas /s/, /j/ e 1 (3,3\%), apresentou distorção do fone /d/.

Em relação a Comunicação Gráfica, observou-se que 16 (53,3\%) alunos apresentaram durante a escrita, postura corporal adequada, e os outros 14 (46,7\%), apresentaram posturas inadequadas.

Quanto ao posicionamento da folha no ato da escrita, observou-se que 16 (53,3\%) escreviam com a folha em posição adequada, e 14 (46,7\%), posicionavam a folha inadequadamente.

Outro dado avaliado foi preensão do lápis no momento de escrever, e verificou-se: preensão adequada em 29 (96,7\%) dos alunos e apenas 1 (3,3\%), apresentando esta inadequada. 
Quanto ao tipo de letra apresentado pelos alunos, pode-se verificar que 27 (90\%) apresentam letras adequadas, e 3 (10\%) apresentam letras mal formadas.

No que diz respeito a organização espacial, 27 (90\%) apresentaram esta noção, e 3 (10\%) não.

Em relação à dominância lateral apresentada pelos alunos triados, verificou-se que 28 (93,3\%) adolescentes têm dominância lateral direita, já 2 (6,7\%), esquerda.

No que diz respeito a investigação quanto aos aspectos miofuncional oral em relação aos lábios, obteve-se 27 (90\%) alunos em relação aos aspectos dos lábios normais, 1 (3,3\%) com lábios entreabertos e 2 (6,7\%) com lábios selados com tensão.

Quanto a investigação de palato duro, verificou-se que 29 (96,7\%) com palato duro normal, e 1 (3,3\%) aluno apresentando palato em ogiva.

O tipo facial predominante no grupo foi o facial médio com 27 (90\%), seguido do longo com $2(6,6 \%)$ e do curto com 1 (3,3\%).

Quanto a triagem da cavidade bucal, observou-se que 7 (23,3\%) alunos apresentavam cáries visíveis a olho nu, 1 (3,3\%) aluno apresentava diastema presente entre os incisivos centrais, e 22 (73,3\%) não apresentavam qualquer tipo de alteração dentária visível.

Os sujeitos, os quais apresentaram nesta avaliação, cárie visível pela Fonoaudióloga, foram encaminhados para os atendimentos Odontológico, realizados na própria Instituição, pelo $4^{\circ}$. ano de Odontologia na Faculdade de Odontologia de Bauru (FOB-USP), para que estes dentes pudessem ser tratados.

Quanto ao posicionamento dos ombros, pode-se observar que 9 (30\%) apresentaram estes adequados, e 21 (70\%) anteriorizados.

Ao que diz respeito a tonicidade e tensão dos lábios obteve-se os seguintes resultados: 29 (96,7\%) apresentando tonicidade normal e, 1 (3,3\%), lábios hipotônicos. 
Quanto a avaliação da tonicidade da bochecha, constatou-se que 29 (96,7\%) tinham tonicidade normal, e 1 (3,3\%), hipotônico.

Quanto a mobilidade de língua verificou-se que 25 (83,3\%) dos alunos apresentaram uma mobilidade adequada, e 5 (16,7\%) apresentaram alteração quando não conseguiram realizar o movimento de vibração de língua.

Em relação a desconforto sentido na palpação da ATM, 24 (80\%) alunos negaram desconforto e 6 (20\%), apresentaram estalo quando foi solicitado abertura, fechamento ou palpação da cavidade oral.

Observou-se que a respiração dos adolescentes era do tipo oro/nasal em 1 (4,5\%), e do tipo nasal em 29 (95,5\%) alunos.

No que diz respeito a mastigação, pode-se notar que 21 (70\%) adolescentes, apresentam mastigação bilateral, 1 (3,3\%), apresenta mastigação unilateral direita, 3 (10\%) apresenta mastigação unilateral esquerda, $4(13,2)$ relataram mastigar bilateralmente, porém, preferem o lado esquerdo, e já 1 (3,3\%), também mastiga bilateralmente, mas tem preferência do lado direito.

Também foram coletados outros dados na triagem, os quais não mostraram alterações em nenhum dos 30 (100\%) alunos participantes, os quais seguem abaixo:

Não foram encontradas em $100 \%$ dos sujeitos, alterações em relação aos aspectos pragmáticos e discursivo narrativo, aspecto Semântico Lexical, compreensão do discurso, as fluências da fala; quanto a leitura, apresentaram esta global em 100\% dos alunos, velocidade adequada, não usaram apoio, respeitaram a entonação, regras de pontuação, e compreenderam o que foi lido na situação de leitura; todos apresentaram nível gráfico esperado pela idade, posicionamento de cabeça, onde todos apresentaram esta centralizada em relação ao corpo, ao palato mole, ao aspecto da língua dos indivíduos, a palpação de localidades na face como nas 
seguintes musculaturas: masseter, pterigoideo lateral, pterigoideo medial, temporal, quanto a mobilidade de bochecha, lábio, bem como a voz e deglutição dos alunos.

\section{ETAPA II}

\section{Questionário Inicial (Apêndice B)}

Tabela 5: Concepção dos alunos em relação às habilidades e dificuldades no que diz respeito as áreas de atuação fonoaudiológicas.

\begin{tabular}{|c|c|c|c|c|}
\hline \multirow{2}{*}{ Questão } & \multicolumn{2}{|c|}{ Sim } & \multicolumn{2}{|c|}{ Não } \\
\hline & $\mathrm{n}$ & $\%$ & $\mathrm{n}$ & $\%$ \\
\hline $\begin{array}{l}\text { Dificuldade de } \\
\text { mastigação }\end{array}$ & 2 & $(6,7)$ & 28 & $(93,3)$ \\
\hline $\begin{array}{l}\text { Dificuldade para } \\
\text { engolir }\end{array}$ & 1 & $(3,3)$ & 29 & $(96,7)$ \\
\hline $\begin{array}{l}\text { Engasgo ou tosse } \\
\text { durante a } \\
\text { alimentação }\end{array}$ & 4 & $(13,3)$ & 26 & $(86,7)$ \\
\hline $\begin{array}{l}\text { Dores/estalos na } \\
\text { ATM }\end{array}$ & 6 & $(20,0)$ & 24 & $(80,0)$ \\
\hline $\begin{array}{l}\text { Dificuldade para } \\
\text { abrir a boca }\end{array}$ & 1 & $(3,3)$ & 29 & $(96,7)$ \\
\hline $\begin{array}{l}\text { Problemas } \\
\text { dentários }\end{array}$ & 16 & $(53,3)$ & 14 & $(46,7)$ \\
\hline $\begin{array}{l}\text { Problemas } \\
\text { respiratórios }\end{array}$ & 4 & $(13,3)$ & 26 & $(86,7)$ \\
\hline Cansaço ao falar & 3 & $(10,0)$ & 27 & $(90,0)$ \\
\hline Já ficou afônico & 6 & $(20,0)$ & 24 & $(80,0)$ \\
\hline $\begin{array}{l}\text { Rouquidão com } \\
\text { facilidade }\end{array}$ & 10 & $(33,3)$ & 20 & $(66,7)$ \\
\hline $\begin{array}{l}\text { Infecção de } \\
\text { garganta }\end{array}$ & 6 & $(20,0)$ & 24 & $(80,0)$ \\
\hline Gosta da voz & 20 & $(66,7)$ & 10 & $(33,3)$ \\
\hline Mudança na voz & 8 & $(26,7)$ & 22 & $(73,3)$ \\
\hline $\begin{array}{l}\text { Dificuldade de } \\
\text { memória }\end{array}$ & 10 & $(33,3)$ & 20 & $(66,7)$ \\
\hline Dificuldade escolar & 7 & $(23,3)$ & 23 & $(76,7)$ \\
\hline $\begin{array}{l}\text { Dificuldade para } \\
\text { memorizar }\end{array}$ & 7 & $(23,3)$ & 23 & $(76,7)$ \\
\hline
\end{tabular}


Tabela 5 (continuação): Concepção dos alunos em relação às habilidades e dificuldades no que diz respeito as áreas de atuação fonoaudiológicas.

\begin{tabular}{|c|c|c|c|c|}
\hline $\begin{array}{l}\text { Dificuldade para } \\
\text { compreender }\end{array}$ & 5 & $(16,7)$ & 25 & $(83,3)$ \\
\hline $\begin{array}{l}\text { Alteração na fala } \\
\text { quando nervoso }\end{array}$ & 10 & $(33,3)$ & 20 & $(66,7)$ \\
\hline Trocas na fala & 9 & $(30,0)$ & 21 & $(70,0)$ \\
\hline $\begin{array}{l}\text { Dificuldade de } \\
\text { escrita }\end{array}$ & 7 & $(23,3)$ & 23 & $(76,7)$ \\
\hline $\begin{array}{l}\text { Troca de letra na } \\
\text { escrita }\end{array}$ & 10 & $(33,3)$ & 20 & $(66,7)$ \\
\hline $\begin{array}{l}\text { Dificuldade para } \\
\text { compreender } \\
\text { quando lê }\end{array}$ & 3 & $(10,0)$ & 27 & $(90,0)$ \\
\hline $\begin{array}{l}\text { Dificuldade para } \\
\text { escrever texto }\end{array}$ & 3 & $(10,0)$ & 27 & $(90,0)$ \\
\hline Erros em ditado & 7 & $(23,3)$ & 23 & $(76,7)$ \\
\hline $\begin{array}{l}\text { Dificuldade para } \\
\text { copiar algo }\end{array}$ & 0 & $(0,0)$ & 30 & $(100,0)$ \\
\hline Gagueja & 7 & $(23,3)$ & 23 & $(76,7)$ \\
\hline $\begin{array}{l}\text { Em qualquer } \\
\text { situação }\end{array}$ & 2 & $(6,7)$ & 28 & $(93,3)$ \\
\hline $\begin{array}{l}\text { Quando fica } \\
\text { nervoso }\end{array}$ & 15 & $(50,0)$ & 15 & $(50,0)$ \\
\hline $\begin{array}{l}\text { Falando com } \\
\text { pessoas estranhas }\end{array}$ & 9 & $(30,0)$ & 21 & $(70,0)$ \\
\hline Familiares & 0 & $(0,0)$ & 30 & $(100,0)$ \\
\hline Ao telefone & 4 & $(13,3)$ & 26 & $(86,7)$ \\
\hline Cantando & 1 & $(3,3)$ & 29 & $(96,7)$ \\
\hline
\end{tabular}

Quanto a velocidade de fala, pode-se observar que 1 (3,3\%) relatou apresentar uma fala lenta, 24 (80\%) uma velocidade normal, e 5 (16,7\%), relataram ter uma fala rápida. 


\section{ETAPA III}

\section{Realização das Oficinas de Aprimoramento da Comunicação Escrita}

Após a nomeada Etapa I e II do presente trabalho, seguiu a Etapa III, que teve como objetivo principal, trabalhar a Escrita destes adolescentes, através de encontros realizados semanalmente, com duração de 1 hora com cada turma participante do "Primeiro Emprego".

Nas oficinas oferecidas para os adolescentes, foram abordados assuntos como:

-Leitura e sua importância

-A concepção de texto

-A coesão

-A coerência

-Aspecto Semântico

-Estrutura sintática

-Léxico

-Erros ortográficos

-Uso adequado da pontuação

- Relação oralidade X escrita

-Elaboração semanal de textos, nos quis eram abordados temas sugerido pelos próprios adolescentes, que eram corrigidos pelos alunos juntamente com a Fonoaudióloga, e neste momento, eram apontadas os acertos e os erros dos alunos em relação a construção textual, bem como erros ortográficos.

Os assuntos foram abordados em diferentes encontros, porém a cada semana, se via a necessidade de realizar uma revisão do assunto abordado anteriormente, onde estes eram discutidos entre eles com a ajuda da Fonoaudióloga. 
Para o desenvolvimento das Oficinas, houve a necessidade da elaboração de planejamento de trabalho, que estão anexados no final deste trabalho (Apêndices D, E, F,G, H, I, J, K), que constam de informações que foram abordadas em sala. Estes eram entregues em todo início dos encontros, para que assim, os alunos pudessem acompanhar o conteúdo oferecido.

\section{ETAPA IV}

\section{Coleta da escrita final e Análise da Comparação entre escrita inicial e escrita final}

Nesta etapa do trabalho, foi realizada uma comparação da Escrita Inicial, coletada através do Protocolo de Triagem Fonoaudiológica (Parte I) com a Escrita Final, sendo esta, a escrita avaliada após a realização das 8 Oficinas oferecidas aos alunos anteriormente já mencionadas.

A tabela 6 mostra a comparação da escrita espontânea com relação a construção do texto, a tabela 7 com relação ao número de parágrafos, e a tabela 8 e 9 com relação aos erros ortográficos.

Podemos verificar na Tabela 6 que quando comparado os dados em relação a coesão, uso de pontuação e sintaxe inicial com o a escrita final, notou-se diferença estatisticamente significante. Quanto ao número de parágrafos também houve diferença estatisticamente significante (Tabela 7). 
Tabela-6: Comparação entre escrita espontânea inicial e final em relação a construção de texto

\begin{tabular}{|c|c|c|c|c|c|c|c|c|c|}
\hline \multirow{3}{*}{ Questão } & \multicolumn{4}{|c|}{ Inicial } & \multicolumn{4}{|c|}{ Final } & \multirow{3}{*}{$\mathrm{p}$} \\
\hline & \multicolumn{2}{|c|}{ Sim } & \multicolumn{2}{|r|}{ Não } & \multicolumn{2}{|r|}{ Sim } & \multicolumn{2}{|r|}{ Não } & \\
\hline & $\mathrm{n}$ & $\%$ & $\mathrm{n}$ & $\%$ & $\mathrm{n}$ & $\%$ & $\mathrm{n}$ & $\%$ & \\
\hline Coesão & 22 & $(73,3)$ & 8 & $(26,7)$ & 29 & $(96,7)$ & 1 & $(3,3)$ & $0,023 *$ \\
\hline Coerência & 29 & $(96,7)$ & 1 & $(3,3)$ & 29 & $(96,7)$ & 1 & $(3,3)$ & $0,480 \mathrm{~ns}$ \\
\hline Uso de pontuação & 21 & $(70,0)$ & 9 & $(30,0)$ & 30 & $(100,0)$ & 0 & $(0,0)$ & $0,008 *$ \\
\hline Léxico & 28 & $(93,3)$ & 2 & $(6,7)$ & 30 & $(100,0)$ & 0 & $(0,0)$ & $0,480 \mathrm{~ns}$ \\
\hline Sintaxe & 19 & $(63,3)$ & 11 & $(36,7)$ & 29 & $(96,7)$ & 1 & $(3,3)$ & $0,004 *$ \\
\hline Erros ortográficos & 16 & $(53,3)$ & 14 & $(46,7)$ & 15 & $(50,0)$ & 15 & $(50,0)$ & $1,000 \mathrm{~ns}$ \\
\hline
\end{tabular}

Tabela-7: Comparação entre o número de parágrafos encontrados na Escrita Espontânea inicial e final

\begin{tabular}{|c|c|c|c|c|c|}
\hline \multicolumn{2}{|c|}{ Inicial } & \multicolumn{2}{|c|}{ Final } & \multirow{2}{*}{$\mathrm{t}$} & \multirow{2}{*}{$\mathrm{P}$} \\
\hline Média & $\mathrm{dp}$ & média & $\mathrm{dp}$ & & \\
\hline 1,50 & 1,07 & 4,20 & 1,81 & 6,872 & $<0,001 *$ \\
\hline
\end{tabular}

Ao comparar os erros ortográficos nas duas situações, não foram achadas diferenças estatisticamente significante em nenhum dos tipos de erros (Tabela 8 e Tabela 9). 
Tabela-8: Comparação entre Ditado inicial e Ditado final em relação aos erros ortográficos encontrados

\begin{tabular}{|c|c|c|c|c|c|c|c|c|c|}
\hline \multirow{3}{*}{ Questão } & \multicolumn{4}{|c|}{ Inicial } & \multicolumn{4}{|c|}{ Final } & \multirow{3}{*}{$\mathrm{p}$} \\
\hline & \multicolumn{2}{|r|}{ Sim } & \multicolumn{2}{|c|}{ Não } & \multicolumn{2}{|c|}{ Sim } & \multicolumn{2}{|r|}{ Não } & \\
\hline & $\mathrm{n}$ & $\%$ & $\mathrm{n}$ & $\%$ & $\mathrm{n}$ & $\%$ & $\mathrm{n}$ & $\%$ & \\
\hline $\begin{array}{l}\text { Representação } \\
\text { Múltipla }\end{array}$ & 23 & $(76,7)$ & 7 & $(23,3)$ & 19 & $(63,3)$ & 11 & $(36,7)$ & $0,289 \mathrm{~ns}$ \\
\hline Apoio na Oralidade & 3 & $(10,0)$ & 27 & $(90,0)$ & 4 & $(13,3)$ & 26 & $(86,7)$ & $1,000 \mathrm{~ns}$ \\
\hline Omissão de Letras & 4 & $(13,3)$ & 26 & $(86,7)$ & 0 & $(0,0)$ & 30 & $(100,0)$ & $0,134 \mathrm{~ns}$ \\
\hline $\begin{array}{l}\text { Junção ou } \\
\text { separação não } \\
\text { convencional de } \\
\text { palavras }\end{array}$ & 20 & $(66,7)$ & 10 & $(33,3)$ & 13 & $(43,3)$ & 17 & $(56,7)$ & $0,096 \mathrm{~ns}$ \\
\hline $\begin{array}{l}\text { Confusão entre ao e } \\
\text { am }\end{array}$ & 3 & $(10,0)$ & 27 & $(90,0)$ & 5 & $(16,7)$ & 25 & $(83,3)$ & $0,617 \mathrm{~ns}$ \\
\hline $\begin{array}{l}\text { Generalização de } \\
\text { regras }\end{array}$ & 12 & $(40,0)$ & 18 & $(60,0)$ & 5 & $(16,7)$ & 25 & $(83,3)$ & $0,096 \mathrm{~ns}$ \\
\hline $\begin{array}{l}\text { Substituição surdo- } \\
\text { sonora }\end{array}$ & 1 & $(3,3)$ & 29 & $(96,7)$ & 3 & $(10,0)$ & 27 & $(90,0)$ & $0,617 \mathrm{~ns}$ \\
\hline Acréscimo de letras & 5 & $(16,7)$ & 25 & $(83,3)$ & 3 & $(10,0)$ & 27 & $(90,0)$ & $0,724 \mathrm{~ns}$ \\
\hline Letras parecidas & 2 & $(6,7)$ & 28 & $(93,3)$ & 0 & $(0,0)$ & 30 & $(100,0)$ & $0,480 \mathrm{~ns}$ \\
\hline Inversão de letras & 0 & $(0,0)$ & 30 & $(100,0)$ & 0 & $(0,0)$ & 30 & $(100,0)$ & $1,000 \mathrm{~ns}$ \\
\hline Outras & 3 & $(10,0)$ & 27 & $(90,0)$ & 0 & $(0,0)$ & 30 & $(100,0)$ & $0,248 \mathrm{~ns}$ \\
\hline
\end{tabular}


Tabela-9: Comparação entre Escrita espontânea inicial e Escrita espontânea final em relação aos erros ortográficos encontrados

\begin{tabular}{|c|c|c|c|c|c|c|c|c|c|}
\hline \multirow{3}{*}{ Questão } & \multicolumn{4}{|c|}{ Inicial } & \multicolumn{4}{|c|}{ Final } & \multirow{3}{*}{$\mathrm{p}$} \\
\hline & \multicolumn{2}{|r|}{ Sim } & \multicolumn{2}{|r|}{ Não } & \multicolumn{2}{|r|}{ Sim } & \multicolumn{2}{|r|}{ Não } & \\
\hline & $\mathrm{n}$ & $\%$ & $\mathrm{n}$ & $\%$ & $\mathrm{n}$ & $\%$ & $\mathrm{n}$ & $\%$ & \\
\hline $\begin{array}{l}\text { Representação } \\
\text { Múltipla }\end{array}$ & 3 & $(10,0)$ & 27 & $(90,0)$ & 4 & $(13,3)$ & 26 & $(86,7)$ & $1,000 \mathrm{~ns}$ \\
\hline Apoio na Oralidade & 2 & $(6,7)$ & 28 & $(93,3)$ & 5 & $(16,7)$ & 25 & $(83,3)$ & $0,248 \mathrm{~ns}$ \\
\hline Omissão de Letras & 1 & $(3,3)$ & 29 & $(96,7)$ & 1 & $(3,3)$ & 29 & $(96,7)$ & $1,000 \mathrm{~ns}$ \\
\hline $\begin{array}{l}\text { Junção ou } \\
\text { separação não } \\
\text { convencional de } \\
\text { palavras }\end{array}$ & 3 & $(10,0)$ & 27 & $(90,0)$ & 4 & $(13,3)$ & 26 & $(86,7)$ & $1,000 \mathrm{~ns}$ \\
\hline $\begin{array}{l}\text { Confusão entre ao e } \\
\text { AM }\end{array}$ & 0 & $(0,0)$ & 30 & $(100,0)$ & 0 & $(0,0)$ & 30 & $(100,0)$ & $1,000 \mathrm{~ns}$ \\
\hline $\begin{array}{l}\text { Generalização de } \\
\text { regras }\end{array}$ & 0 & $(0,0)$ & 30 & $(100,0)$ & 0 & $(0,0)$ & 30 & $(100,0)$ & $1,000 \mathrm{~ns}$ \\
\hline $\begin{array}{l}\text { Substituição surdo- } \\
\text { sonora }\end{array}$ & 0 & $(0,0)$ & 30 & $(100,0)$ & 0 & $(0,0)$ & 30 & $(100,0)$ & $1,000 \mathrm{~ns}$ \\
\hline Acréscimo de letras & 1 & $(3,3)$ & 29 & $(96,7)$ & 0 & $(0,0)$ & 30 & $(100,0)$ & $1,000 \mathrm{~ns}$ \\
\hline Letras parecidas & 0 & $(0,0)$ & 30 & $(100,0)$ & 0 & $(0,0)$ & 30 & $(100,0)$ & $1,000 \mathrm{~ns}$ \\
\hline Inversão de letras & 0 & $(0,0)$ & 30 & $(100,0)$ & 0 & $(0,0)$ & 30 & $(100,0)$ & $1,000 \mathrm{~ns}$ \\
\hline Outras & 2 & $(6,7)$ & 28 & $(93,3)$ & 1 & $(3,3)$ & 29 & $(96,7)$ & $1,000 \mathrm{~ns}$ \\
\hline
\end{tabular}




\section{ETAPA V}

Questionário Final (Apêndice C): Concepção do aluno sobre os encontros realizados

Tabela-10: Percepção dos adolescentes em relação as Oficinas de Aprimoramento da Comunicação escrita

\begin{tabular}{|c|c|c|c|c|}
\hline \multirow{2}{*}{ Questão } & \multicolumn{2}{|c|}{ Sim } & \multicolumn{2}{|c|}{ Não } \\
\hline & $\mathrm{n}$ & $\%$ & $\mathrm{n}$ & $\%$ \\
\hline $\begin{array}{l}\text { Importância dos } \\
\text { encontros }\end{array}$ & 26 & $(86,7)$ & 4 & $(13,3)$ \\
\hline $\begin{array}{l}\text { Mudanças na } \\
\text { Leitura e na escrita }\end{array}$ & 29 & $(96,7)$ & 1 & $(3,3)$ \\
\hline $\begin{array}{l}\text { Trocas de } \\
\text { experiência }\end{array}$ & 29 & $(96,7)$ & 1 & $(3,3)$ \\
\hline $\begin{array}{l}\text { Mudança na } \\
\text { comunicação }\end{array}$ & 26 & $(86,7)$ & 4 & $(13,3)$ \\
\hline $\begin{array}{l}\text { Estratégias } \\
\text { fornecidas }\end{array}$ & 30 & $(100,0)$ & 0 & $(0,0)$ \\
\hline $\begin{array}{l}\text { Planos explicativos } \\
\text { foram } \\
\text { complementares }\end{array}$ & 29 & $(96,7)$ & 1 & $(3,3)$ \\
\hline $\begin{array}{l}\text { Linguagem } \\
\text { acessível }\end{array}$ & 26 & $(86,7)$ & 4 & $(13,3)$ \\
\hline $\begin{array}{l}\text { Linguagem dos } \\
\text { planos foram } \\
\text { acessíveis }\end{array}$ & 29 & $(96,7)$ & 1 & $(3,3)$ \\
\hline $\begin{array}{l}\text { Assuntos } \\
\text { abordados foram } \\
\text { adequados }\end{array}$ & 28 & $(93,3)$ & 2 & $(6,7)$ \\
\hline Restaram dúvidas & 2 & $(6,7)$ & 28 & $(93,3)$ \\
\hline $\begin{array}{l}\text { Carga horária } \\
\text { suficiente }\end{array}$ & 25 & $(83,3)$ & 5 & $(16,7)$ \\
\hline Sugestões & 4 & $(13,3)$ & 26 & $(86,7)$ \\
\hline
\end{tabular}




\section{DISCUSSÃO}

Para iniciar a discussão do presente trabalho, vê-se a necessidade de ressaltar aqui, a dificuldade que se teve, ao realizar uma busca na literatura sobre o assunto "Aprimoramento da comunicação”, principalmente quando se buscava o assunto escrita. Foram realizadas buscas nas seguintes bases de dados: Lilacs, Pubmed, Scielo, e mesmo Google, onde foram encontrados assuntos como Aprimoramento vocal, Aprimoramento em empresas entre outros, porém, pouco se encaixa no presente trabalho, o que levou a uma breve revisão de literatura quanto a este assunto.

Também não foram encontrados dados em literatura que justificam a eficiência da realização de Oficinas trabalhando a comunicação escrita, mas com este trabalho, podemos constatar que, estas promovem mudanças significativas quanto a comunicação dos adolescentes, justificando assim a eficiência deste.

Ferreira (1995), Blos (1998), Villarreal (2001), Canongia (2000), Doron (1998) concordam quando dizem que acontecem inúmeras mudanças no período da adolescência, as quais caracterizam-se por mudanças corporais, psicológicas, e refletem em todas as facetas do comportamento, maturação física, e também a maturidade sexual adulta. Canongia (2000) ainda complementa que é uma fase de grandes transformações, na qual existe a necessidade de se tornar independente, afetando assim o desenvolvimento de seus interesses, seu comportamento social e qualidade de vida afetiva.

No que diz respeito a idade referente ao período da adolescência, o Estatuto da Criança e do Adolescente (ECA) e a Organização Mundial de Saúde (OMS) discordam nas idades. De acordo com ECA a idade compreendida é de 12 a 18 anos, já para a OMS, esta fase é compreendida dos 10 aos 19 anos, porém sabe-se que esta oscilação deve-se ao fato de que o critério etário não pode ser tomado isoladamente para caracterizar essa fase. Vale ressaltar que 
os alunos que participaram desta pesquisa encontram-se na faixa etária de 15-18 anos, sendo assim, são considerados adolescentes pela OMS e ECA.

Gontijo e Medeiros (2004), Mauro, (1995) concordam em suas citações quando dizem que devido a desigualdade social que existe em nosso país, podemos ver hoje, a maioria dos adolescentes da considerada classe popular, ou baixa, procurando um trabalho, este fato acontece devido aos adolescentes tentar suprir as dificuldades financeiras encontradas no âmbito domiciliar.

A busca do emprego na adolescência, está diretamente ligada a baixa renda recebida pelas famílias hoje em dia em nosso país, assim, podemos observar a busca dos adolescentes no mercado de trabalho pois eles trabalhando, estarão aumentando a renda de toda a família e ajudando assim a sobrevivência de todos. Este fato, já não é encontrado na classe média, devido as famílias terem uma renda maior, não sendo necessário que seus filhos procurem emprego para ajudar nos gastos da casa e mesmo, suprir suas necessidades materiais, tendo apenas a obrigação de estudar.

Os autores Santos (1997), Neto (1998), Mauro (1995) concordam quando dizem que é na adolescência que os jovens procuram o mercado de trabalho, sendo na maioria, esta procura, não voluntaria, mas sim para ajudar em casa, devido as dificuldades financeiras encontradas nas famílias de classe baixa. Estes autores também relatam que, usualmente, os trabalhos oferecidos a esses adolescentes são atividades monótonas, braçais, repetitivas, desinteressantes e desestimulantes, e não se consegue um bom salário. Santos (1997) e Vicente (1994), ainda complementam estes dados, referindo que os adolescentes ao iniciarem o trabalho precocemente, são diretamente prejudicados em seu rendimento escolar, não se constituindo nem em estudantes que trabalham, nem, trabalhadores que estudam. Levando em consideração a colocação do autor acima, devemos salientar aqui, que hoje em dia, devido ao grande número de alunos inseridos em uma mesma sala no ensino público, o rendimento e aprendizagem ficam 
comprometidos, e devido ao fato de não existir repetição de série, estes passam para séries superiores, com inúmeros conhecimentos não aprendidos, os quais poderão prejudicá-los futuramente.

Existem muitas instituições em nosso país, que oferecem programas para adolescentes em busca do Primeiro Emprego. Isto acontece devido a grande necessidade destes adolescentes precisarem trabalhar. De acordo com, Forster et al (1992), Bandeira et al (1994) e Brito (1999), essas instituições, são de recreação, programas governamentais, não governamentais, religiosos, e também programas que oferecem aos adolescentes oficinas profissionalizantes que fornecem a classe social desfavorecida, uma alimentação, educação, lazer e prestação de cuidados com a higiene e a saúde, sendo assim a "Casa do Garoto”, um exemplo deste tipo de instituição.

De acordo com dados trazidos pelo MEC, até o final do ensino fundamental, os alunos têm que ter pleno domínio da leitura, escrita e cálculo. Sendo escrita avaliada neste trabalho, e tendo a análise destes, tabulados nos "Resultados" nas tabelas 6, 7, 8, 9 podemos salientar aqui que estes freqüentadores do ensino fundamental público não saem desta etapa escolar com domínio pleno da escrita, ficando aqui uma questão. Será o ensino fundamental eficiente em relação aprendizagem da leitura e da escrita para a aprendizagem em nosso país? Está é uma questão que merece atenção e atitudes imediatas, pois, caso contrário, teremos na próxima década, adultos considerados analfabetos funcionais. Encontramos nestes adolescentes, principalmente, erros ortográficos, mais também erros em relação a estrutura necessária para construção de um texto.

De acordo com informações trazidas pelo Brasil (2004), Guedes (1997), Sacalosky, Alavarsi e Guerra (2000), Kyrillos, Martins e Ferreira (1997), Zorzi (1999) e Colaço (1991), o Fonoaudiólogo quando inserido no âmbito escolar, tem como característica principal, realizar atividades de caráter preventivo e não terapêutico. Foi elaborado uma Oficina de 
Aprimoramento da Comunicação escrita, com intuito de beneficiar os alunos, oferecendo maneiras adequadas para a realização de construção de textos, bem como incentivo dos alunos a leitura, que muito referiram nos encontros, não terem este hábito, o que é muito importante para “escrever bem”, e podemos constatar após a realização destes encontros que quando um fonoaudiólogo trabalha em um âmbito escolar, este é capaz de conseguir mudanças positivas, como no caso, aconteceu após as oficinas realizadas neste trabalho, como podemos observar nas tabelas 6, 7, 8 e 9 deste trabalho.

Pacheco e Caraça (1989), Collaço (1991), Kyrillos, Martins e Ferreira (1997), Sacalosky, Alavarsi e Guerra (2000), concordam quando ressaltam em seus trabalhos a importância da relação Fonoaudiólogo e outros profissionais dentro da escola para a realização de um bom trabalho, alegando que quando se realiza um trabalho em equipe, conclui-se qual é melhor conduta para assim passar esta para o professor, já que é ele quem fica com a criança ou adolescente na maior parte do tempo no período em que este está escola. Considerando os dados acima, devemos destacar aqui a parceria entre Fonoaudióloga, Psicóloga e Professora de Informática a qual aconteceu no decorrer deste trabalho. Em todos os encontros realizados, eram discutidos casos dos alunos e chegava-se a conclusão de qual conduta tomar em relação a certo aluno. Mostrando assim que é de grande importância o trabalho em equipe e não individual, onde se pode trocar conhecimentos e chegar a conclusão de qual é a melhor conduta para o aluno.

Quanto a comunicação, ponto principal deste trabalho, Stefanelli, Carvalho e Arantes (2005), Corraze (1982), Mendes (1994), Sfez (1994), Megginson et al. (1986), concordam que a comunicação nada mais é do que um processo de integração, transformação, um processo de compreender e transmitir mensagem, compartilhar idéias e transferir informações. Sendo a comunicação uma das áreas de trabalho do Fonoaudiólogo, esta foi avaliada por meio de uma 
triagem e trabalhada com os adolescentes inseridos no primeiro emprego através da realização as Oficinas de Aprimoramento da Comunicação escrita.

De acordo com Mesquita (1997) e Stefanelli (1993), a comunicação pode ser dividida em dois tipos, sendo elas: comunicação verbal (oral ou escrita) e comunicação não verbal, as quais se diferenciam pelo fato da comunicação verbal acontecer através de palavras, verbalizações e escrita; já a não verbal, destacada entre os autores, um tipo de comunicação que pode nos trazer informações as vezes, mais verdadeiras do que as verbais. Completando esses dados, Mesquita (1997), Corraze (1982), Davis (1979) e Lemos (2006), informam que este tipo de comunicação acontece através de gestos, olhares, trejeitos.

Podemos observar na análise dos resultados dessa pesquisa, em relação a escrita antes da Oficina, que, alguns alunos apresentaram erros ortográficos do tipo: representação múltipla, apoio na oralidade, acréscimo de letras, entre outros, como mostrado detalhadamente na tabela 6 e já 8 (26,7\%) alunos não apresentaram coesão textual, 1 (3,3\%) apresentou um texto sem coerência, 9 (30\%) não faziam uso correto de pontuação, 1 (3,3\%) não acessaram o léxico corretamente, e 11 (36,7\%) apresentaram alterações de sintaxe. Devido a estas dificuldades, a Oficina de Aprimoramento da Comunicação Escrita, foi criada para que os alunos pudessem melhor sua qualidade de comunicação considerando que a comunicação escrita é um dos critérios para a seleção quando se fala da disputa de uma vaga de emprego. Após a realização das Oficinas de Aprimoramento da Comunicação realizadas com estes alunos, obteve-se mudanças estatisticamente significantes no que diz respeito a coesão $p=0,041$, uso de pontuação $\mathrm{p}=0,013$ e sintaxe $\mathrm{p}=0.023$, quando comparados a escrita inicial e final dos alunos. As oficinas tiveram como objetivo superar e/ou minimizar as alterações encontradas nestes alunos, para prepará-lo para a concorrência do mercado de trabalho.

Lofiego (1995), já dizia que para se escrever bem, o escritor deve apresentar um bom conhecimento de linguagem interiormente. Assim, considerando os resultados obtidos no que 
diz respeito a elaboração da linguagem escrita, Fávero, Andrade e Aquino (2000) relatam em seu trabalho que a escrita, é mais complexa do que a fala, ressaltando que a grande diferença é que na construção do texto, não se trata apenas de conteúdo semântico, mas sim da utilização correta das marcas dos processo de produção, levando o leitor a compreender o que foi lido.

Tais diferenças também demarcadas por Koch (1997) podem ser visualizadas na tabela elaborada por ele e mostrada neste trabalho, que nos proporciona assim, uma maneira mais simples para compreender a grande diferença. Considerando os dados acima, e comparando esses achados do autor acima citado com a escrita apresentada pelos alunos do "Primeiro Emprego”, observou-se, que os alunos triados, apresentaram uma comunicação escrita, aquém do esperado, devido a esta, estar muito próxima da linguagem oral (fala), não mostrando nelas, a “diferença de complexidade”, que a escrita deveria ter.

De acordo com Koch e Travaglia (1990), Koch (1998), Brasil (2001), Sayeg-Siqueira (1990), texto é uma unidade linguística com propriedades estruturais específicas, utilizadas pelos usuários da língua (falante, escritor/ouvinte, leitor), e não se trata apenas de uma seqüência de frases isoladas, mas sim, uma unidade lingüística com propriedades estruturais específicas.

Como citado por Nascimento (1999) e Pimenta, Lima e Francisco (2004), hoje em dia nas empresas, os gerentes, ao selecionarem seus trabalhadores, exigem deles, uma comunicação adequada. Considerando os dados acima, bem como os dados obtidos no desenrolar deste trabalho, nos deparamos com adolescentes portadores de uma comunicação escrita prejudicada, que podemos observar a partir dos dados nas tabelas 6, 7, 8, 9. Correlacionando as Oficinas realizadas para amenizar ou eliminar as dificuldades destes adolescentes bem como analisando os dados obtidos no Questionário Final (Apêndice C) aplicado no final deste trabalho, podemos concluir que a maioria dos adolescentes 26 (86,7\%) julgaram ser importante a realização dos 
encontros, sendo que 29 (96,7\%) alunos informaram que após a realização destes, perceberam mudanças em relação a sua escrita.

Outro dado importante trazido pelos alunos através deste questionário, é que 26 (86,7\%) deles, relataram após a realização das Oficinas, ter percebido mudança na sua comunicação, julgando adequados os assuntos abordados nas Oficinas, como podemos ver na tabela 10 .

Considerando os dados acima discutidos, pode-se concluir que o presente trabalho, obteve-se resultados positivos, quando avaliado a escrita inicial e final dos alunos, mostrando assim a importância da realização de um Aprimoramento da Comunicação Escrita com eles, devido aos alunos do Ensino Público em nosso país, apresentarem na maioria uma escrita deficitária, e após as Oficinas realizadas, mostrarem uma evolução estatisticamente significante em alguns aspectos.

Frente ao exposto, segue abaixo sugestões de temas para serem trabalhados em um próximo trabalho com adolescentes freqüentadores do curso "Primeiro Emprego" oferecido pela Diocese de Bauru Divino Espírito Santo (Casa do Garoto Rogacionista), na cidade de Bauru-SP: Leitura; Oratória; Ortografia; Voz; Terapia em grupo para alunos que apresentam mesmo tipo de alteração, bem como encaminhamento de alunos para a Faculdade de Odontologia de Bauru (FOB-USP), quando a dificuldade não puder ser trabalhada em grupo.

Devido a disponibilidade dispensada pela Assistente Social da Instituição, esta, oferece total apoio para qualquer atividade que oferece benefício aos alunos provenientes do curso “Primeiro Emprego”, como trabalhos abordando assunto relacionados a dificuldades nas áreas da fonoaudiologia, já que de acordo com a Assistente Social, os adolescentes lá inseridos, apresentam inúmeras dificuldades quando a comunicação. 


\section{Conclusão}

Com os resultados desta pesquisa pode-se concluir que:

1) Quanto a caracterização das amostras da comunicação oral e escrita dos adolescentes, podemos concluir que a comunicação gráfica está aquém do esperado para a idade destes adolescentes, devido a estes, não terem pleno domínio da escrita, principalmente quanto aos aspectos ortográficos e na concepção de construção de texto, nos aspectos de coesão, coerência, pontuação, aspecto semântico, estrutura sintática e relação oralidade e escrita.

2) Quanto a caracterização das alterações fonoaudiológicas encontradas nos adolescentes através da triagem, tivemos como resposta alterações quanto a mastigação, respiração, alterações fonéticas, escrita e não presença de hábito de leitura.

3) No que diz respeito as Oficinas realizadas durante este trabalho, foram abordados diferentes, assuntos tais como: Leitura e sua importância, a Concepção de Texto, Coesão, Coerência, Aspecto Semântico, Estrutura Sintática, Léxico, Erros Ortográficos; Uso adequado da pontuação bem como a Relação oralidade X escrita, com o objetivo de aprimorar suas habilidades comunicativas no que diz respeito à linguagem escrita.

4) A comparação da escrita inicial com a escrita final (após a realização das Oficinas), teve como resultados, dados estatisticamente significantes, comprovando uma melhora na construção textual, porém quando aos erros ortográficos apresentados inicialmente, não se obteve dados significantes de melhora. 
5) A percepção dos adolescentes sobre as Oficinas realizadas, segundo os alunos do “Primeiro Emprego” foram importantes, devido a promoção de mudanças no que diz respeito ao seu modo de escrever e mesmo oralmente. 


\section{REFERÊNCIAS BIBLIOGRÁFICAS}

1.ABAURRE, M. B. Linguagem ora, linguagem escrita: interessam à Linguiística os dados da aquisição da representação escrita da linguagem? IX Congresso Internacional da ALFAL. Campinas 1990.

2. ABAURRE, M. B. M.;SILVA, A. D. O desenvolvimento de critérios de segmentação na escrita. Temas em Psicologia, v.1, n. 1, p. 89-102. 1993.

3. AKKARI, A. J. Desigualdades educativas estruturais no Brasil: entre estado, privatização e descentralização. Educ. Soc., v.22, n. 74, p. 163-189. 1996.

4. ALVEZ, M. A. J. Repensando algumas questões sobre o trabalho infanto-juvenil. Revista Brasileira de Educação, v.19, n. 1, p. 87-98, Jan/Abr. 2002.

5.ALVIM, M. R. B.;VALLADARES, L. P. Infância e sociedade no Brasil: uma análise da literatura. Boletim Informativo e Bibliográfico, v.26, n. 2, p. 3-37. 1988.

6. _ـ Infância e sociedade no Brasil: uma análise da literatura. Boletim Informativo e Bibliográfico, v.26, n. 2, p. 3-37. 1998.

7. ALVIM, R. Família e trabalho Infantil. Boletim Informativo e Bibliográfico, v.2, n. 2, p. 213-231. 2001.

8. ARAÚJO, U. I. Coesão e coerência como padrões de textualidade em produções escolares. 1997. 340 f. - Faculdade de Filosofia, Letras e Ciências Humanas, Universidade de São Paulo, São Paulo, 1997.

9. BANDEIRA, D. et al. O cotidiano dos meninos de rua de Porto Alegre. Anais do XVII International School Psychology Congress: 133-134 p. 1994.

10. BENEDICT, H. Early lexical development: comprehension and production. J Child Lang, v.6, n. 1, p. 183-200, Aug. 1979.

11. BILAC, E. D. Familias de trabalhadores: estrategias de sobrevivencia. Ensaio e Memória, v. 9, n. 3, p. 157. 1978.

12. BLOS, P. Adolescência: uma interpretação psicanalítica. Psicologia e Critica, n., p. 26-48. 1998.

13. BRAGA, M. E.;M.J.P., S. Comunicação competente: visão de enfermeiros especialistas em comunicação. Acta paul. enferm, v.20, n. 4, p. 410-414. 2007.

14. BRASIL. Estatuto da Criança e do Adolescente - ECA. MINISTÉRIO JUSTIÇA: Diário Oficial. Lei 8069 de 13 de julho de 1990, 2001.

15. . Secretaria de Educação Fundamental. Parâmetros curriculares nacionais terceiro e quarto ciclos do ensino fundamental: língua portuguesa/ Secretaria de Educação Fundamental. . Brasília :MEC/SEF, 1998.106 p. 
16. Conselho Federal de Fonoaudiologia. Resolução Cffa No 305/2004. Regulamenta os direitos e deveres dos inscritos nos Conselhos de Fonoaudiologia, segundo suas atribuições específicas. Diário Oficial, 2004. p.10.

17. . Cartilha do Trabalhador. Resolução No 153/2006. Direitos constitucionais do trabalhador. Diário Oficial, 2007. p. 59.

18. BRITO, R. C. Uso de drogas entre meninos e meninas em situação de rua: Subsídios para uma intervenção comunitária. 1999. 134 f. (Dissertação) - Curso de Pós-graduação em Psicologia do Desenvolvimento, Universidade Federal do Rio Grande do Sul, Porto Alegre, 1999.

19. CAGLIARI, G. M. O texto na alfabetização ed. Campinas: Mercado de Letras, 2001. 35$93 \mathrm{p}$.

20. CALDANA, M. L. Elaboração de Textos Narrativos por Alunos da Terceira Série: Análise da Produção Oral e Escrita de Alunos de duas Escolas Públicas. 2002. 153 f. (Tese) Letras, Universidade Estadual Paulista "Julio de Mesquita Filho", Araraquara, 2002.

21. CANONGIA, M. B. Adolescência. In: (Ed.). Intervenção Precoce em Fonoaudiologia. Rio de Janeiro: Revinter Ltda, 2000. Adolescência, p.35-36

22. CASTAÑO, J. Bases neurobiológicas del lenguaje y sus alteraciones. Rev Neurol, v.36, n. 1, p. 781-785. 2003.

23. CAVALHERO, M. T. P. Formação do fonoaudiólogo no Brasil: estrutura curricular e enfoque preventivo. 1996. 126 f. (Dissertação) - Instituto de Psicologia da Pontifícia Universidade Católica de Campinas, Campinas, 1996.

24. CERVINI, R.;BURGER, F. O menino trabalhador no Brasil. O trabalho e a rua: crianças e adolescentes no Brasil urbano dos anos 80. FAUSTO, A. CERVINI, R. São Paulo: Cortez: 17-46 p. 1991.

25. CHAFE, W. L. Linguistics differences produced by differences between speaking and writing. In: OLSON, D. R. E. A. (Ed.). Literacy, language and learning. Cambridge: Cambridge University Press, 1985. Linguistics differences produced by differences between speaking and writing., p.105-123

26. COLLAÇO, N. L. O fonoaudiólogo e a escola. In: (Ed.). Fonoaudiologia Escolar: As Origens de uma Proposta. São Paulo: Sammus Editorial, 1991. O fonoaudiólogo e a escola, p.21-28

27. CORRAZE, J. As comunicações não-verbais. ed. Rio de Janeiro: Zahar, 1982. 45-78 p.

28. DAUSTER, T. Uma infância de curta duração: trabalho e escola. Cadernos de Pesquisa., v.82, n. 1, p. 31-36. 1992.

29. DAVIS, F. A comunicação não-verbal. ed. São Paulo: Summus, 1979. 25-37 p. 
30. DORON, R.;PAROT, F. Dicionário de Psicologia. Dicionário de Psicologia. São Paulo: Ática 1998.

31. FÁVERO, L. L. Coesão e coerência textual. ed. São Paulo: Ática, 1991. 130 p.

32. FÁVERO, L. L.; ANDRADE, M. L. C. V. O.;AQUINO, Z. G. O. Oralidade e escrita: Perspectiva para o ensino de língua materna. 2 ed. São Paulo: Cortez, 2000. 15-50 p.

33. FERREIRA, A. B. H. Dicionário Aurélio Básico da Lingua Portuguesa. Rio de Janeiro: Nova Fronteira: 390 p. 1995.

34. FERREIRA, S. P. A.;DIAS, M. D. G. B. B. A escola e o ensino da leitura. Psicol. estud., v.7, n. 1, p. 39-49. 2002.

35. FERREIRO, E.;TEBEROSKY, A. Psicogênese da língua escrita. ed. Porto Alegre: Artes Médicas, 1986

36. FORSTER, L. M. K. et al. Meninos na rua: Relação entre abuso de drogas e atividades ilícitas. Revista da ABP-APAL, v.14, n. 2, p. 115-120. 1992.

37. FOUCAMBERT, J. A leitura em questão. ed. Porto Alegre: Artes Médicas, 1994

38. FRANCISCHINI, R. Linguagem oral - linguagem escrita: elementos conjuntivos na produção de narrativas por crianças em processo formal de aquisição de escrita. 1990. $159 \mathrm{f}$. (Dissertação) - Instituto de Psicologia, Universidade de São Paulo, São Paulo, 1990.

39. FREIRE, P. E. Extensão ou comunicação? 7 ed. Rio de Janeiro: Paz e Terra, 1983. 93p p.

40. GOMES, J. V. Vida familiar e trabalho de crianças e de jovens pobres. Cadernos de Psicologia e Educação, v.15, n., p. 45-61. 1998.

41. GONÇALVES, F.;DIAS, M. G. B. B. Coerência textual: um estudo entre jovens e adultos. Psicologia: Reflexão e Crítica, v.16, n. 1, p. 29-40. 2003.

42. GONTIJO, D. T.;MEDEIROS, M. Gravidez / maternidade e adolescentes em situação de risco social e pessoal: algumas considerações. Revista Eletrônica de Enfermagem, v.06, n. 03, p. 2004.

43. GUEDES, Z. C. F. A atuação do Fonoaodiólogo e seu Papel na Escola. ed. São Paulo: Lovise, 1997. 119-137 p.

44. GUMPERZ, J.; KALTMAN, H.;O'CONNOR, M. Cohesion in spoken and whitten discourse: ethnic style and the transition do literacy. In: TANNEM, D. (Ed.). Coherence in Spoken and written discourse. Norwood, New Jersey: Ablex Publishing Corpotations, 1984. Cohesion in spoken and whitten discourse: ethnic style and the transition do literacy., p.2-19

45. HALLIDAY, M. A. K. Spoken and written language. ed. Oxford: Oxford University Press, 1989

46. HALLIDAY, M. A. K.;HASAN, H. Coeson in english. ed. London: Longman, 1976 
47. KNAPP, M. L. La comunicacion non verbal: el cuerpo y el entorno. ed. Barcelona: Paidós Ibérica, 1982

48. KOCH, I. G. V. O texto e a contrução dos sentidos. ed. São Paulo: Contexto, 1997 (Coleção Caminhos da Linguística,

49. A coesão textual. ed. São Paulo: Contexto, 1998. 75 p.

50. KOCH, I. G. V.;TRAVAGLIA, L. C. A coerência textual. ed. São Paulo: Contexto, 1990. $10 \mathrm{p}$.

51. . A coerência textual. ed. São Paulo: Cortez, 1999

52. KREPS, G. L. La Comunicación en las Organizaciones. ed. New York: Wilmington Delaware, 1995

53. KRESS, G. Learning to write. ed. London: Routle \& Kegan Paul, 1982

54. KYRILLOS, L.; MARTINS, K.;FERREIRA, P. Fonoaudiologia e escola: a aprendizagem de uma visão preventiva. A fonoaudiologia nas instituições. LAGROTTA, M. G. M. CÉSAR, C. P. H. R. São Paulo: Lovise: 93-97 p. 1997.

55. LAUNAY, C.;BOREL- MAISONNY, S. Distúrbios de linguagem, da fala e da voz na infância. ed. São Paulo: Livraria Roca Ltda, 1989

56. LEMOS, I. S. A comunicação não verbal: um Estudo de Caso. UNIrevista, v.1, n. 3, p. 136-140. 2006.

57. LOFIEGO, J. L. Evolução do grafismo. In: (Ed.). Disgrafia: avaliação fonoaudiológica. Rio de Janeiro: Revinter, 1995. Evolução do grafismo, p.51-71

59. LOPES, M. A. R. Constituição da República Federativa do Brasil. Revista dos Tribunais, v.12, n. 2, p. 78-81. 1996.

60. LOURDES, M.;MATENCIO, M. Leitura, produção de textos e a escola: reflexões sobre o processo de letramento. ed. Campinas: Mercado de Letras, 1994. 111 p.

61. LURIA, A. R. Fundamentos de Neuropsicologia. ed. Rio de Janeiro: S.A., 1981

62. MACHADO NETO, Z. Meninos Trabalhadores. Cadernos de Pesquisa., v.31, n., p. 95101. 1979.

63. MADEIRA, F.;BERCOVICH, A. A “onda jovem” e seu impacto na População Economicamente Ativa de São Paulo. Planejamento e políticas públicas, v.8, n., p. 34-56. 1992.

64. MASSINI-CAGLIARI, G. O texto na alfabetização - coesão e coerência. ed. Campinas: Mercado de Letras, 2001. 136 p. 
65. MAURO, M. L. F. O adolescente trabalhador e suas ralações familiares. Cadernos de Pesquisa NEP, v.1, n. 2, p. 37-50. 1995.

66. MEGGINSON, L. M.; MOSLEY, D. C.;PIETRI, P. H. J. Administração Conceitos e Aplicações. ed. São Paulo: Harbra, 1986

67. MENDES, I. A. C. Enfoque humanistico à comunicação em enfermagem. ed. São Paulo: Sarvier, 1994

68. MESQUITA, R. M. Comunicação Não-Verbal: Relevância na Atuação Profissional. Rev. Paul. Educ. Fís, v.11, n. 2, p. 155-63, jul/dez. 1997.

69. Ministério da Educação, INEP. Censo Escolar 2006.

70 . , Secretaria da educação básica, 2008.

http://portal.mec.gov.br/seb/ Acesso em: 20 ago. 2008

71. MUSSEN, P. H. et al. Desenvolvimento e personalidade da criança. 3 ed. São Paulo: Harbra, 1995. 515 p.

72. NASCIMENTO, V. M.; CRUZ, A. L. G.;ABREU, A. F. O Sistema de comunicação e a Gestão dos Fluxos Logísticos na Construção Civil: Estudo Aplicado ao Gerenciamento de processos Empresariais. ed. São Paulo: PMI, 1999

73. NETO, A. M. Q. F. Família Operária e Reprodução da Força de Trabalho. ed. Petrópolis: Vozes, 1982

74. NETO, O. C.;MOREIRA, M. R. Child and adolescent labor: factors, legal aspects, and social repercussions. Cadernos de Saúde Pública, v.14, n. 2, p. 54-59. 1998.

75. OLIVEIRA, B. R. G.;ROBAZZI, M. L. C. C. O trabalho na vida dos Adolescentes: Alguns fatores determinantes para o trabalho precoce. Rev Latino-am Enfermagem, v.9, n. 3, p. 83-9, maio. 2001.

76. PACHECO, E. C.;CARAÇA, E. B. Fonoaudiologia escolar. In: FERREIRA, L. P. et al. (Ed.). Temas em fonoaudiologia. São Paulo: Loyola, 1989. Fonoaudiologia escolar, p.201-9

77. PASCHOALIN, M. A.;SPADOTO, N. T. Gramática: Teoria e exercícios. ed. São Paulo: FTD, 2000. 402-3 p.

78. PASSADORI, R. Para que Aprimorar a Comunicação: Jornal da Comunicação corporativa, 2008.

79. PASSETTI, E. O menor no Brasil República. In: ORGANIZAÇÃO et al. (Ed.). História da criança no Brasil. São Paulo: Contexto, 1991. O menor no Brasil República, p.146-175

80. PEREIRA, L. D.; SANTOS, A. M. S.;OSBORN, E. Ação Preventiva na Escola: Aspectos Relacionados com a Integração Professor e Aluno e a Comunicação Humana. In: (Ed.). Fonoaudiologia e Saúde Publica. Carapicuiba: Pro Fono, 2000. Ação Preventiva na Escola: 
Aspectos Relacionados com a Integração Professor e Aluno e a Comunicação Humana., p.197-214

81. PIMENTA, R. B.; LIMA, I., A;;FRANCISCO, A. C. Comunicação Eficaz: Competência Gerenciais Gerencial Estratégica para o Compartilhamento do Conhecimento nas Organizações. XI SIMPEP. Bauru 2004.

82. RECTOR, M.;TRINTA, A. A comunicação não-verbal: a gestualidade brasileira. ed. Petrópolis: Vozes, 1985

83. REGO, L. L. B.;BUARQUE, L. L. Consciência sintática, consciência fonológica e aquisição de regras ortográficas. Psicologia: reflexão e critérios, v.10, n. 2, p. 199-217. 1997.

84. ROMANELLI, G. Famílias de classes populares: socialização e identidade masculina. Cadernos de Pesquisa NEP, v.1, n. 2, p. 25-34. 1997.

85. SACALOSKI, M.; ALAVARSI, E.;GUERRA, G. R. Fonoaudiologo e Professor: uma parceria fundamental. In: (Ed.). Fonoauiologia na escola. Sao Paulo: Lovise, 2000. Fonoaudiologo e Professor: uma parceria fundamental, p.19-24

86. SACALOSKY, M.; ALAVARSI, E.;GUERRA, G. R. Fonoaudiologo e Professor: uma parceria fundamental. In: (Ed.). Fonoauiologia na escola. Sao Paulo: Lovise, 2000. Fonoaudiologo e Professor: uma parceria fundamental, p.19-24

87. SALGADO, C.;CAPELLINI, S. A. Desempenho em leitura e escrita de escolares com transtornos fonológicos. Psicol Esc Educ, v.8, n. 2, p. 179-88. 2004.

88. SANTOS, C. M. Lugar de criança é no trabalho? As perversas estratégias de sobrevivência do núnleo família na cidade do Rio de Janeiro. Revista da Faculdade de Serviço Social da UERJ, v.11, n. 1, p. 11-15. 1997.

89. SAYEG-SIQUEIRA, J. H. O texto: movimentos de leitura, táticas de produção, critérios de avaliação. ed. São Paulo: Selinunte, 1990.93 p.

90. SCHIAVONI, A. Dificuldades de aprendizagem em escrita e percepção de alunos sobre expectativas de professores. 2004. 123 f. (Dissertação) - Faculdade de Educação, Universidade Estadual de Campinas, Campinas, 2004.

91. SFEZ, L. Crítica da comunicação. ed. São Paulo: Loyola, 1994

92. SHARE, L. Phonological recoding and self-teaching: sine qua non of reading acquisition. Cognition, v.55, n. 2, p. 151-218. 1995.

93. SILVA, M. J. P. Comunicação tem remédio: a comunicação nas relações interpessoais em saúde. ed. São Paulo: Loyola, 2006

94. SMITH, F. Compreendendo a leitura. Uma análise psicolinguística da leitura e do aprender a ler. ed. Porto Alegre: Artes Médicas, 1982 
95. STEFANELLI, M. C. Comunicação com o paciente: teoria e ensino. ed. São Paulo: Robe, 1993

96. STEFANELLI, M. C.; CARVALHO, E. C.;ARANTES, E. C. A comunicação nos diferentes contextos de Enfermagem. ed. Barueri: Manole, 2005

97. TAKAHASHI, R. T.;PEREIRA, L. L. Liderança e comunicação. Rev. Esc. Enfermagem USP, v.25, n. 2, p. 123-35. 1991.

98. TANNEN, D. Oral and literate strategies in spoken and written narratives. Language, v.58, n. 1, p. 1-21. 1982.

99. TRAVERSO-YÉPEZ, M. A.;PINHEIRO, V. S. Adolescência, Saúde e Contexto Social: Esclarecendo Práticas. Psicologia \& Sociedade, v.14, n., p. 133-147, jul/dez. 2002.

100. VEIGA, J. P. C. A questão do trabalho infantil. In: DEDECCA, C. S. O. (Ed.). Mercado de trabalho. São Paulo: ABET, v.7, 1998. A questão do trabalho infantil.

101. VICENTE, C. M. O direito à convivência familiar e comunitária: uma política de manutenção do vínculo. In: (ORG.), S. M. K. (Ed.). Família Brasileira - a base de tudo. São Paulo: Cortez, 1994. O direito à convivência familiar e comunitária: uma política de manutenção do vínculo., p.40-65

102. VILLARREAL, I. Psicologia para Educadores. ed. Rio de Janeiro: Orión Plus, 1998

103. VYGOTSKY, L. S. Pensamento e Linguagem. 2 ed. São Paulo: Martins Fontes, 1989

104. A Formação Social da Mente. 4 ed. São Paulo: Martins Fontes, 1991

105. WIDDOWSON, H. G. Teaching language as comunication. ed. Oxford Oxford University Press., 1978

106. ZORZI, J. L. Aprender a escrever: a apropriação do sistema ortográfico. ed. Porto Alegre: Artmed, 1998

107. Possibilidades de trabalho do fonoaudiólogia no âmbito escolar-educacional. $\underline{\mathrm{J}}$ Cons Fed Fonoaudiol, v.4, n. 2, p. 211-7. 1999.

108. Consciência fonológica, fases de construção da escrita e seqüência de apropriação da ortografia do português. In: MARCKESAN, I. ZORZI, J. L. (Ed.). Anuário Cefac de fonoaudiologia. Rio de Janeiro: Revinter, 1999/2000. Consciência fonológica, fases de construção da escrita e seqüência de apropriação da ortografia do português, p.91-117

109. Aprendizagem e distúrbios da linguagem escrita: Questões Clínicas e educacionais. ed. São Paulo: Arimed, 2003. 9-27 p.

110. Desvios na ortografia. In: FERREIRA, L. P.;BEFI-LOPES, D. M. LIMONGE, S. C. O. (Ed.). Tratado de Fonoaudiologia. São Paulo: Roca, v.68, 2005. Desvios na ortografia, p.878-91 
111. ZARAFIAN, P. El modelo de competência y tos sistemas productivos. ed. Montevideo: Cinterfor, 1999.

112. ZUANETTI, P. A.; CORRÊA-SCHNEK, A. P.;MANFREDI, A. K. S. Comparação dos erros ortográficos de aluno com desempenho inferior em escrita e alunos com desempenho médio nesta habilidade. Rev Soc Bras Fonoaudiol, v.13, n. 3, p. 240-5. 2008. 


\section{TERMO DE CONSENTIMENTO LIVRE E ESCLARECIDO}

O projeto tem como objetivo, avaliar os adolescentes inseridos na "Casa do Garoto", os quais estão em busca do primeiro emprego. Estes, a princípio, irão passar por uma avaliação fonoaudiológica individual para ver quais são suas dificuldades, em seguida os que apresentarem alguma alteração em relação os padrões de normalidade da comunicação, irão, participar de Oficinas de Aprimoramento da Comunicação para Inclusão dos Jovens no Mercado de Trabalho, a qual tem como objetivo, favorecer as habilidades de comunicação oral, escrita, voz e motricidade orofacial de adolescentes, contribuindo para sua inclusão formal no mercado de trabalho através do aprimoramento de sua comunicação.

Os riscos desta pesquisa para os sujeitos são próximos à zero já que apresenta intervenção que são considerados não invasivos, os resultados serão sigilosos e também não terá nenhum custo para os pacientes já que todo o material necessário será fornecido pela equipe de pesquisa. Com relação aos benefícios, se feito de acordo com as orientações passadas pela fonoaudióloga, os adolescentes poderão melhorar sua comunicação para facilitar seu engajamento no mercado de trabalho.

Os adolescentes que participarão deste projeto, não terão custo nenhum.

Telefones para contato:

Mestranda, Fernanda Menechino Costa: (14) 32349619

Comitê de Ética e Pesquisa (FOB-USP): (14) 32358356

Pelo presente instrumento que atende às exigências legais, o Sr. (a)

portador da cédula de identidade __ , após leitura minuciosa das informações constantes neste TERMO DE CONSENTIMENTO LIVRE E ESCLARECIDO, devidamente explicada pelos profissionais em seus mínimos detalhes, ciente dos serviços e procedimentos aos quais será submetido, não restando quaisquer dúvidas a respeito do lido e explicado, firma seu CONSENTIMENTO LIVRE E ESCLARECIDO concordando em participar da pesquisa proposta.

Fica claro que o sujeito da pesquisa ou seu representante legal, pode a qualquer momento retirar seu CONSENTIMENTO LIVRE E ESCLARECIDO e deixar de participar desta pesquisa e ciente de que todas as informações prestadas tornaram-se confidenciais e guardadas por força de sigilo profissional (Art. $29^{\circ}$ do Código de Ética do Fonoaudiólogo).

Por estarem de acordo assinam o presente termo.

Bauru-SP, de de. 


\section{Universidade de São Paulo \\ Faculdade de Odontologia de Bauru}

Al. Dr. Octávio Pinheiro Brisolla, 9-75 - Bauru-SP - CEP 17012-901 - C.P. 73

PABX (0XX14)3235-8000 - FAX (0XX14)3223-4679

Comitê de Ética em Pesquisa (14)3235-8356

e-mail: mferrari@fob.usp.br

Processo $n^{\circ} 91 / 2007$

Bauru, 29 de junho de 2007.

Senhor Professor,

O projeto de pesquisa encaminhado a este Comitê de Ética em Pesquisa em Seres Humanos, denominado "Oficinas de aprimoramento da comunicação para inclusão dos jovens no Mercado de Trabalho", de autoria de Fernanda Menechino Costa, que será desenvolvido sob sua orientaçăo, foi enviado ao relator para avaliação

Na reunião de 27 de junho de 2007 o parecer do relator, aprovando o projeto, foi aceito pelo Comitê, considerando que năo existem infraçőes éticas pendentes.

Informamos que após o envio do trabalho concluído, este Comitê enviará o parecer final, que será utilizado para publicação do trabalho.

Atenciosamente,

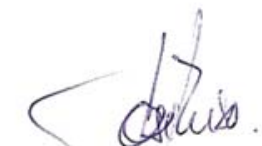

Prof. Dr. Josè Henrique Rubo Cogrdenador

Prof. Dr. José Roberto Pereira Lauris

Docente do Departamento de Odontopediatria, Ortodontia e Saúde Coletiva 


\section{(Apêndice A)}

\section{PROTOCOLO DE TRIAGEM FONOAUDIOLÓGICA}

\section{I - IDENTIFICAÇÃo:}

Nome:

Escolaridade:

Data:

\section{II - LinguAgEM ORAL:}

\section{Aspecto Pragmático e Discurso Narrativo}

$\begin{array}{llll}\text { - Habilidades conversacionais } & \text { ( ) respeita os turnos } & \text { ( ) mantém tópico da conversação } \\ \text { - Funções comunicativas } & \text { ( ) solicita } & \text { ( ) nomeia } & \text { ( ) usa expressões sociais } \\ \text { - Discurso Narrativo: } & \text { ( ) coerência } & \text { ( ) coesão } & \text { ( ) domínio de expressões }\end{array}$
temporais
- Discurso Narrativo:
( ) coerência
( ) coesão
( ) domínio de expressões

Aspecto Morfossintático

- Orações

- Períodos

- Desvio de flexionamento

( ) uso de preposições
( ) Afirmativas

( ) simples

( ) verbal

( ) artigos
( ) Negativas

( ) composto

( ) nominal

( ) elementos de ligação
( ) Exclamativas ( ) Interrogativas

( ) advérbios

Aspecto Semântico-Lexical
- Acesso ao léxico
( ) adequado
( ) tempo aumentado

\section{Aspecto Fonológico}

- Processos fonológicos

Ex:

\section{Aspecto Fonético}

$\begin{array}{lllr}\mathrm{p} & \mathrm{t} & \mathrm{k} & \text { grupos consonantais: } / \mathrm{l} / \\ \mathrm{b} & \mathrm{d} & \mathrm{g} & \mathrm{r} / \\ \mathrm{f} & \mathrm{s} & \varsigma & {[1]} \\ \mathrm{v} & \mathrm{z} & \gamma & \text { arquifonemas: }[1] \\ \mathrm{m} & \mathrm{n} & \eta & \text { africadas: } / \mathrm{t} \mathrm{s} / \\ & \mathrm{l} & \lambda & / \mathrm{d} \gamma /\end{array}$

Compreensão do Discurso

( ) total ( ) parcial ( ) nula

IV - FLUÊNCIA:

- Velocidade de fala

( ) normal

( ) diminuída

( ) aumentada

- Manifestações lingüísticas

( ) prolongamentos

( ) hesitações( ) bloqueios ( ) repetições 
- Manifestações neurovegetativas ( ) sudorese

( ) tremores

( )outras -Manifestaç̃es

\section{V - ComuniCAČ̃̃o Gráfica:}

\begin{tabular}{|c|c|c|c|}
\hline & Adequada & Inadequada & \\
\hline - Postura & ( ) & ( ) & \\
\hline - Posição da folha & $($ ) & ( ) & \\
\hline - Preensão do lápis & ( ) & ( ) & \\
\hline - Pressão do lápis & ( ) & ( ) forte & ( ) fraca \\
\hline - Tipo de letra & ( ) & ( ) micrografia & ( ) letras malformadas \\
\hline - Organização espacial & ( ) & $($ ) & \\
\hline
\end{tabular}

- Dominância lateral ( ) destro

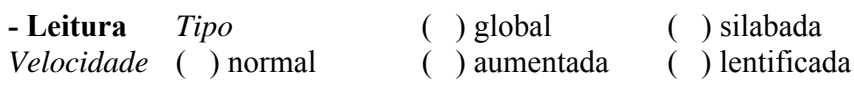

$\begin{array}{llll}\text { Apoio } & \text { ( ) ausente } & \text { ( ) digital } & \text { ( ) articulatório } \\ \text { Entonação } & \text { ( ) presente } & \text { ( ) ausente } & \\ \text { Regras pontuação ( ) respeito } & \text { ( ) não respeito } & \\ \text { Compreensão } & \text { ( ) nenhuma } & \text { ( ) parcial } & \text { ( ) total }\end{array}$

Em anexo para análise:

-Escrita espontânea

-Ditado oral

-Cópia
- Nível gráfico
( ) pré-silábico
( ) silábico
( ) silábico-alfabético
( ) alfabético

VIII - ASPECTOS CLÍNICOS OROMIOFUNCIONAIS:

Aspectos Morfológicos

- Lábios Aspecto: ( ) normal ( ) alterado
( ) selados s/ tensão
( ) selados c/ tensão
( ) entreabertos
( ) abertos

Postura:

- Língua Aspecto: ( ) norma

( ) geográfica

( ) sulcada

( )fissurada

Postura ápice: ( ) papila palatina

( ) região alveol. infer. ( ) entre dentes

- Palato duro $\quad$ Aspecto: $\quad$ ( )normal $\quad$ ( ) raso $\quad$ ( ) ogival

operado
- Palato mole
Aspecto:
( ) extensão normal
( ) extensão curta
- Tonsilas palatinas Aspecto:
( ) nos pilares
( ) além dos pilares
( ) distendendo as fauces

( ) toca na linha média ( ) não observável
- Tipo facial ( ) médio
( ) longo
( ) curto

- Dentes e oclusão

( ) falhas dentárias

( ) mordida aberta

( ) mordida cruzada

( ) sobremordida
- Postura corporal
Cabeça: ( ) centralizada
( ) inclinada D
( ) inclinada $\mathrm{E}$
Ombros:
( ) adequados
( ) elevado D
( ) elevado E

( ) anteriorizados

Sistema Sensório Motor Oral
- Tonicidade/ Lábios ( ) normal
( ) hipotônicos
( ) hipertônicos
Tensão
Bochecha:
( ) normal
( ) hipotônicos
( ) hipertônicos 


$\begin{array}{llll}\text { Mento: } & \text { ( ) normal } & \text { ( ) hipotônicos } & \text { ( ) hipertônicos } \\ \text { Língua: } & \text { ( ) normal } & \text { ( ) hipotônicos } & \text { ( ) hipertônicos }\end{array}$

- Mobilidade/ Marcar os movimentos realizados sem dificuldades
Motricidade Bochechas:
( ) inflar
( ) suflar
( ) inflar alternadamente
Lábios:
( ) estalo
( ) vibração
( ) $\mathrm{o} / \mathrm{i} / \mathrm{o} / \mathrm{i} / \mathrm{o} / \mathrm{i}$
Língua: ( ) protruir e retrair ( ) pontos cardeiais ( ) estalo
( ) vibração
$M d b: *$
( ) abertura
( ) fechamento
( ) protrusão
( )lateraliz. D ( ) lateraliz. E

- Dor à palpação
( ) ( ) masseter
( ) ( ) pterigóideo lateral

( ) ( ) temporal

( ) ( ) pterigóideo medial

( ) ( ) ATM

Funções

- RespiraçãoModo:

( ) nasal Apreensão: ( ) c/ dentes

\section{( ) buco/nasal}

( ) bucal

( ) bi. simultânea ( ) uni. D

( ) c/ mãos

Tipo:

( ) bi. alternada

( ) uni. E

\section{- Deglutição}

( ) adequada

Interp. Ling ( ) anterior

( ) adaptada

( ) posterior

- Voz

Tipo ( ) normal

( ) rouca

( ) áspera

( )outro 


\section{(Apêndice B)}

\section{QUESTIONÁRIO}

Nome:

Data:

\section{MOTRICIDADE OROFACIAL}

a) Apresenta dificuldade para mastigar os alimentos?

( ) $\operatorname{sim}$ ( ) não

b) Apresenta dificuldade para engolir os alimentos?

( ) $\operatorname{sim}$ ( ) não

c) Engasga ou tosse durante a alimentação com freqüência?

( ) $\operatorname{sim}$

( ) não

f) Apresenta dores e/ou estalos na ATM?

( ) $\operatorname{sim}$

( ) não

g) Apresenta dificuldade ao abrir a boca?

( ) $\operatorname{sim}$

( ) não

i) Apresenta problemas dentários?

( ) $\operatorname{sim}$

( ) não

j) Apresenta problemas respiratórios?

( ) $\operatorname{sim}$

( ) não

\section{VOZ}
a) Apresenta dores, queimação e/ou cansaço ao falar ?
( ) $\operatorname{sim}$
( ) não
b) Já ficou afônico (sem voz)?
( ) $\operatorname{sim}$
( ) não
c) Fica rouco com facilidade?
( ) $\operatorname{sim}$
( ) não
d) Em que período é mais perceptível a rouquidão?
( ) $\mathrm{M}$
( ) $\mathrm{T}$
( ) $\mathrm{N}$
e) Apresenta infecções de garganta com freqüência?
( ) $\operatorname{sim}$
( ) não
f) Gosta da sua voz?
( ) $\operatorname{sim}$
( ) não
g) Nota mudanças na sua voz?
( ) $\operatorname{sim}$
( )não

\section{LINGUAGEM ORAL}

a) Apresenta dificuldade para lembrar das palavras quando está conversando com as pessoas? ( ) sim ( ) não
b) Apresenta dificuldades escolares?
( ) $\operatorname{sim}$ ( ) não

c) Sente dificuldade para memorizar dados recentes (ex: memorizar um número de telefone para discar imediatamente)?

$$
\text { ( ) } \operatorname{sim} \text { ( ) não }
$$

d) Apresenta dificuldade para compreender o que é dito? (Necessita que a pessoa fique explicando mais de uma vez o que disse?)
( ) $\operatorname{sim}$
( ) não
( ) $\operatorname{sim} \quad$ ( ) não
( ) $\operatorname{sim}$ ( ) não

e)Você percebe alterações na sua fala quando fica nervoso?

f)Apresenta trocas na fala?

g) Como você julgaria sua fala?

( ) Lenta

( ) Normal

( ) Rápida 


\section{LINGUAGEM ESCRITA}

a)Você tem dificuldades na escrita?

( ) $\operatorname{sim}$ ( )não

b) Apresenta trocas de letras quando escreve?

( ) $\operatorname{sim}$ ( ) não

c) Você tem dificuldade de compreender quando lê?

( ) $\operatorname{sim}$ ( )não

d) Sente dificuldade para escrever um texto?

( ) $\operatorname{sim} \quad($ ) não

e)Quando participa de ditados, apresenta muitos erros?

( ) $\operatorname{sim}($ ) não

f) Sente dificuldade quando copia alguma escrita?

( ) $\operatorname{sim}$

( ) não

\section{FLUÊNCIA}

a) Você gagueja quando fala?

( ) $\operatorname{sim} \quad$ ( )não

b) Em qualquer situação?

( ) $\operatorname{sim} \quad($ )não

c) Normalmente quando fica nervoso?

( ) $\operatorname{sim} \quad($ )não

d) Quando conversa com pessoas estranhas?

( ) $\operatorname{sim}$ ( )não

e) Quando conversa com familiares?

( ) $\operatorname{sim}$ ( )não

f)Gagueja quando fala ao telefone?

( ) $\operatorname{sim}$ ( )não

g) Quando canta?

( ) $\operatorname{sim}$ ( )não 
(Apêndice C)

\section{QUESTIONÁRIO FINAL APLICADO AOS SUJEITOS DE PESQUISA}

Nome:

Data:

1. Você julgou importante a realização dos encontros?

( ) $\operatorname{sim}$ ( ) não

2. Os encontros proporcionaram mudanças no que diz respeito a sua comunicação?

( ) $\operatorname{sim} \quad$ ( ) não

3. Durante os encontros, houve trocas de experiências entre os participantes?

( ) $\operatorname{sim} \quad$ ( ) não

4. As orientações proporcionaram mudanças na sua comunicação?

( ) $\operatorname{sim} \quad$ ( ) não

5. As estratégias fornecidas foram úteis?

( ) $\operatorname{sim}$ ( ) não

6. A linguagem utilizada durante os encontros foi acessível?

( ) $\operatorname{sim} \quad$ ( ) não

7. Os assuntos abordados nos encontros corresponderam às suas necessidades e expectativas?
( ) $\operatorname{sim}$
( ) não

Caso negativo, por quê?

8. Após o desenvolvimento do programa, restam dúvidas a serem esclarecidas?

( ) $\operatorname{sim}$ ( )não

Caso afirmativo, quais?

9. O que achou da carga horária?

( ) suficiente ( ) não suficiente

10. Tem alguma sugestão para a continuidade desse programa?

( ) $\operatorname{sim}$ ( )não

Caso afirmativo, qual(is)? 


\title{
(Apêndice D)
}

\section{Planejamento de Trabalho}

\section{Assunto: A CONCEPÇÃO DE TEXTO}

\section{Definição:}

Todo trecho falado ou escrito que constitui um todo unificado e coerente dentro de uma determinada situação discursiva. Assim, o que define texto não é sua extensão (pode ser eventualmente uma só palavra, uma frase, um diálogo, períodos correlacionados na escrita), mas o fato de que é uma unidade de sentido em relação a uma situação.

O principal atributo de um texto- para ser considerado tal- é UNIDADE. A unidade de um texto se define em princípio, pela sua completude- sem o que o texto não poderá ser reconhecido em sua totalidade, nem por suas partes. Sendo assim, um texto tem UNIDADE quando diversas partes se juntam e se articulam, formando um todo único que pode ser identificado em sua totalidade e em suas partes.

\section{Diferentes tipos de narrativas:}

-Estórias: designam aquelas narrativas que, na ordenação temporal/causal dos eventos, apresentam invariabilidade de conteúdo, ou seja, aquelas que tem enredo fixo, do tipo "Chapeuzinho Vermelho". Mas marcas mais salientes que podem ser identificadas na estrutura das “estórias” são: era uma vez, saí, então, um belo dia, acabou a estória, morreu vitória, foram felizes para sempre.

-Relatos: São narrativas construídas para recuperar lingüisticamente uma seqüência de experiências pessoais pelo narrador. Pode observar nos relatos a falta de compromisso com um enredo fixo, mas com a verdade, onde se começa narrar experiências efetivamente vividas.

-Casos: Não tem compromisso, nem com o enredo fixo - ao contrário da estória - nem com a "verdade", ao contrário dos relatos. Os Narrados, nos casos, podem organizar evento/ações de natureza diversa, em sequências temporais não determinadas previamente, não tendo compromisso com o fato realmente ocorrido.

\section{Mais definições:}

Lopes (1993): Um texto escrito não se restringe apenas à transposição de palavras da linguagem oral para sua representação com caracteres do sistema de escrita. Um texto escrito tem convenções próprias que o tornam diferentes do texto oral em muitos aspectos da organização do discurso. Se a escola não ensinar essas converções, o aluno terá um texto escrito, na melhor das hipóteses, refletindo a linguagem oral, e portanto, não adequado à forma escrita.

Koch (1998): "Um texto não é simplesmente uma seqüência de frases isoladas, mas uma unidade linguística com propriedades estruturais específicas.”

\author{
-Elaboração de texto \\ -A leitura e sua importância
}




\title{
(Apêndice E)
}

\author{
Planejamento de Trabalho
}

\section{Assunto : A COESÃo}

\section{Introdução:}

O processo de transição da linguagem oral para a linguagem escrita envolve muitos aspectos, mas basicamente se concentra na passagem de uma estrutura linguística (fala) para outra (escrita) bastante diferente. A diferença mais acentuada no plano da estruturação frasal, que apresenta unidade sintática e semântica distintas, pois, na elaboração oral, o sujeito lança mão de recursos próprios da fala, como a entonação, as hesitações, as pausas, as repetições, que não estão presentes na escrita de um texto. A escrita é a modalidade em que as frases denotam a transferência de um pensamento completo, no qual as sentenças de inter-relacionam.

Kress (1982) salientou que, na fala, uma frase sucede a outra em uma cadeia que não prediz, necessariamente, o ponto final. Desse modo, numa seqüência de frases, cada frase do turno contribui para adicionar alguma informação ao tópico e ao desenvolvimento geral do texto. A sentença organiza-se de modo diferente, demandando alguma referência a um pensamento completo.

\section{Definição:}

Fávero (1992): Coesão refere-se aos modos como os componentes do universo textual, isto é, as palavras que ouvimos ou vemos, estão ligadas entre si dentro de uma seqüência.

Kopschitz (1994), afirmou que a coesão é a relação explícita entre as proposições expressas pelas frases - onde é possível reconhecer a existência de uma relação entre os atos inlocucionais que as proposições realizam (os quais poder ser ligados de forma não explícita) - percebendo, assim a coerência do discurso. A autora também verificou que a coesão não é a causa da coerência; é o efeito; e a determinação da coesão e coerência depende muito do ouvinte.

A coesão, por estabelecer relação de sentido, diz respeito ao conjunto de recursos semânticos por meio dos quais uma sentença se liga com a que veio antes, aos recursos semânticos mobilizados com o propósito de criar textos.

Coesão significa ligado, é a propriedade que os elementos textuais têm de estar interligados. De um fazer referência ao outro. Do sentido de um depender da relação com o outro. Preste atenção a este texto, observando como as palavras se comunicam, como dependem uma das outras.

Pode-se concluir que a analise da coesão textual se refere, sobretudo, aos elementos textuais responsáveis pelo encadeamento/estruturação dos enunciados.

\section{-Leitura e elaboração de texto.}




\section{(Apêndice F)}

\section{Planejamento de Trabalho}

\section{Assunto: A COERÊNCIA}

\section{Introdução:}

A coerência textual ou o estabelecimento do sentido, depende das informações que o destinatário domina para a "decodificação" do texto e é por isso que a coerência de um texto está ligada a um conhecimento prévio e recíproco entre os interlocutores.

Para o leitor, se não existe continuidade de sentido entre as informações, o texto se apresentará incoerente. E se o texto for incoerente em determinadas situações de comunicação, é preciso esmiuçar as condições específicas desta incoerência. Porém, vale lembrar que um texto pode ser incoerente para um leitor e não para outro, por isso a coerência não pode ser vista de modo linear, ao contrário, ela se determina em situações específicas.

\section{Definição:}

Kopschitz (1994) definiu coerência como: "um fenômeno que diz respeito diretamente à interpretação do texto por parte do interlocutor, ou seja, é um fenômeno ligado diretamente à interlocução"

Dicionário GOOGLE: conexão; harmonia; ligação; estado de coerente.

\section{Curiosidades:}

Alguns autores consideram que a coesão textual é em grande parte responsável pela coerência, ou seja, pela compreensão de um enunciado. "O princípio das relações coesivas está determinado pelo fato de a interpretação de um elemento estar na dependência de outro elemento anterior (ou de outros elementos anteriores). É por isso que se entende o discurso como uma sucessão de informações. A cada ponto do discurso, uma nova informação vai surgindo e ligando-se à anterior, vão se estabelecendo relação entre as informações que vão facilitar o reconhecimento da mensagem" (Araújo, 1997).

\section{Conclusão:}

Coesão e coerência são características de um mesmo fenômeno lingüístico, a construção de um texto, porém, a coesão está ligada à estrutura microtextual, que significa dizer que a coesão corresponde às ocorrências entre unidades menores que compõem o discurso e estabelece relações entre as partes; já a coerência, a estrutura macrotextual, que é o fruto de uma operação que, embora envolva todas as partes do texto, vai buscar a sua inteligibilidade no todo.

\section{Chegamos}

E é um

Primeiro: Hoje é meu último dia de aula! Aula a qual não comparecerei pelo motivo vou escrever mais embaixo. Mas, sabem, eu vou sentir falta do cursinho, me diverti e fiz alguns amigos 
lá! Entre eles o que mais se destaca é o meu professor de direito, o Ângelo! Pelo nome já deu pra notar que não deve se tratar de uma criatura muito normal, não é mesmo? Pode apostar que não, acho que algumas coisas vêm com o nome mesmo. Ele é bem gordinho, canta, dança, representa (esta descrição lembrou alguem?), fazendo estas coisas ele torna muito mais interessantes as aulas de D. Constitucional, D. Penal e Processo civil(por acaso vc já imaginou alguém divertindo-se enquanto estuda estas matérias?), Mas vou expllicar pq vou me lembrar para sempre deste professor, um dia, inadvertidamente, me referi depreciativamente à pessoas obesas, e, pro meu azar, ele ouviu!! Daí ganhei o apelido de "Meio quilo" !!! Pronto, essa seria a vingança do gordinho contra a baixinha magrela!!! Em contra partida eu o chamo de "Xará Tonelada" !! Como esse apelido eu ganhei num curso anterior, quando comecei este que estou fazendo, o apelido pegou!

Segundo:Hoje tem festa infantil!! (oba), festa infantil e de familia tem fama de ser a coisa mais chata do mundo. E eu até que considerava assim. Durante toda a minha adolescencia (q acabou de acabar, ou taval nem tenha acabado) eu odiava aquelas festinhas, os adultos me tratavam como criança e eu ficaria ridicula no meio delas. né??!! Adolescentes lá?? Até podia ter, mas adolescentes nem se misturam, não é? Mas agora, sei lá ó porquê, tudo mudou e eu posso aproveitar o melhor dos dois mundos: - Posso bater um papo com as mulheres mais velhas, lembrando que os respectivos maridos delas estarão em sua própria roda. - Posso bancar a babá e curtir com as crianças, geralmente a minha atenção é voltada para as pequenas Marina, lara e Larissa, até porque, todos os meus outros primos ou são moleques, que estarão jogando video game ou futebol, ou são adolescentes, que, à exemplo de mim, também não se

misturam!

Tenho que parar de escrever agora e não consigo encontrar um fim coerênte para este texto, por um motivo óbvio: $\mathrm{O}$ texto não tem coerência! Ah! E agora?? Escrevo tudo de novo? Tento fazer este monte de baboseira se tornar interessante? Apago tudo e deixo quieto?

Não! Nada disso. Já sei que ninguém vai ler tudo mesmo, entào deixo tudo como está e encerro de maneira

"E

foram absurdamente original.: felizes pra sempre"

FIM! 


\section{(Apêndice G)}

\section{Planejamento de Trabalho}

\section{Assunto: SEMÂNTICO E ESTRUTURA SINTÁTICA}

\section{Semântica}

Refere-se ao estudo do significado, em todos os sentidos do termo. A semântica opõe-se com frequência à sintaxe, caso em que a primeira se ocupa do que algo significa, enquanto a segunda se debruça sobre as estruturas ou padrões formais do modo como esse algo é expresso (por exemplo, escritos ou falados).

\section{Sintaxe e Pontuação:}

Como se sabe, a pontuação é uma convenção que não se destina simplesmente a imitar a fala, mas a ordenar a escrita de acordo com um código padrão específico. Para dominar as regras de pontuação, é importante que se tenha algumas noções de Sintaxe.

Sintaxe de uma língua é a "parte da Gramática que se ocupa das relações que as palavras contraem na frase", ou seja, correspondem à ordenação das palavras em unidades maiores - os sintagmas. A organização dos sintagmas, por sua vez, implica a formação de orações que, unidas, compõem períodos. Por conseguinte, a ordenação de períodos forma textos. Veja:

\section{PALAVRAS $\rightarrow$ SINTAGMAS $\rightarrow$ ORAÇÃO $\rightarrow$ PERÍODO $\rightarrow$ TEXTO}

Pode-se dizer, ainda, que a Sintaxe, ou seja, a organização de uma língua, implica algumas relações fundamentais, como a regência, a concordância, a colocação.

O termo regência, derivado do verbo reger, significa 'comando, governo, direção'. Num sentido amplo, é o verbo que rege todos os termos da oração. Por exemplo, na frase Aquelas crianças abandonadas devoraram os alimentos que chegaram, é possível observar que o verbo "devorar" pressupõe que "alguém" devora "algo". Esse "alguém", ou seja, aquilo de que estamos falando é denominado o sujeito da oração. Já esse "algo" é complemento do verbo em questão e, juntamente com ele, é considerado como aquilo que dizemos a respeito, ou seja, o predicado da oração.

A concordância, por sua vez, é decorrente das relações de regência numa oração. O elemento que determina a concordância verbal é o sujeito. Logo, a melhor definição de sujeito seria "o elemento com o qual o verbo concorda". Já o predicado seria "tudo o que se diz do sujeito".

A colocação é o mecanismo que regula a disposição espacial das palavras na frase. O modo de dispor as palavras varia de língua para língua: cada uma possui os seus próprios mecanismos de colocação. Uma frase está em ordem direta quando as palavras se dispõem na progressão do antecedente para o conseqüente, isto é:

\section{SUJEITO $\rightarrow$ VERBO $\rightarrow$ COMPLEMENTOS DO VERBO $\rightarrow$ ADJUNTOS}

Exemplo: Os EUA $\rightarrow$ criticaram $\rightarrow$ o Iraque $\rightarrow$ com severidade 


\title{
(Apêndice H)
}

\author{
Planejamento de Trabalho
}

\section{Assunto: LÉXICO}

\section{Definição:}

Poderia ser definido como o acervo de palavras de um determinado idioma. Em outras palavras, é todo o conjunto de palavras que as pessoas de uma determinada língua têm à sua disposição para expressar-se, oralmente ou por escrito. Podemos dizer que uma característica básica do léxico é sua mutabilidade, já que ele está em constante movimento. É só notarmos o fato de que palavras se tornam arcaicas, outras são incorporadas, outras mudam seu sentido, e, tudo isso ocorre de forma gradual e quase imperceptível. O sistema léxico de uma língua traduz a experiência cultural acumulada por uma sociedade através do tempo, ou seja, o léxico pode ser considerado como o patrimônio vocabular de uma comunidade lingüística através de sua história, um acervo que é transmitido de uma geração para a geração seguinte.

O usuário da língua utiliza o léxico, esse inventário aberto de palavras disponíveis no seu idioma, para a formação do seu vocabulário, para sua própria expressão no momento da fala e para a efetivação do processo comunicativo. Assim, o vocabulário de um indivíduo caracteriza-se pela seleção e pelos empregos pessoais que ele faz do léxico. Quanto maior for o vocabulário do usuário, maior a possibilidade de escolha da palavra mais adequada ao seu intento expressivo.

\section{Composição:}

O léxico de um idioma é composto de palavras semânticas que podem ser, e realmente o são, agrupadas em classes, conforme prescreve a gramática do idioma. Há tipos de palavras que existem em praticamente todos os idiomas, como os substantivos, os adjetivos e os verbos. O léxico, ou melhor, uma parte do léxico do idioma pode ser encontrado em dicionários de diversos tamanhos. Quanto maior o tamanho, maior o conjunto de palavras e definições que poderão ser contempladas com um espaço naquela obra.

\section{Curiosidades:}

Halliday (1989) afirmou que a linguagem falada é mais dispersa, mais complexa sintaticamente, ao passo que a linguagem escrita é mais condensada, pois nela há maior densidade lexical.

Os escritores usam palavras significantemente mais difíceis do que os falantes quando ambos produzem um discurso sobre o mesmo tema; além disso, a linguagem falada contém menos substantivos abstratos, sendo significante menos abstrata e mais contextualizada.

Quando falamos de crianças, Benedict (1979) afirmou que existem dois grandes fatores que contribuem para o desenvolvimento lexical nos primeiros anos de vida: o imput lingüístico dos pais e as habilidades cognitivas. $\mathrm{O}$ autores, em seus estudos, concluiu que os pais participam da aquisição de novos vocábulos pelas crianças e as influenciam na escolha das palavras.

Barrett (1997) determinou três característica no desenvolvimento lexical inicial. A primeira, se definiu pelo aumento da proporção de substantivos comuns no vocabulário das crianças, à medida 
que o tamanho total do vocabulário cresce de zero para cem palavras. Na segunda característica, o autor enumerou que a proporção dos verbos no vocabulário das crianças começa a aumentar à medida que o vocabulário crescem até valer-se de quatrocentas a quinhentas palavras, ponto em que o aumento da proporção de verbo finalmente começa a se nivelar. Por fim, ele sugeriu que a proporção de adjetivos nos vocabulários das crianças também começa a aumentar à medida que o tamanho do vocabulário total cresce, valendo-se inicialmente de cinqüenta a cem palavras até passar a conter quinhentas palavras ou mais.

Santos \& Navas (2002) afirmam que o crescimento do vocabulário não cessa e que as estimativas apontam que crianças com quatro anos possuem um vocabulário de 2.500 a 3.000 palavras; com sete anos, de 7 a 10 mil palavras; com onze anos, já possuem um vocabulário de 40 mil palavras, sendo que, essa reestruturação ocorre de forma gradual, dependendo de diversos fatores, dentre os quais se salienta a familiaridade e a similaridade sonora entre as palavras do vocabulário. 


\section{(Apêndice I)}

\section{Planejamento de Trabalho}

\section{Assunto: ERROS ORTOGRÁFICOS}

\section{Introdução:}

O ensino tradicional enfatiza que, durante o processo de apropriação da língua escrita, os erros ortográficos não devem ocorrer com freqüência, sendo considerados, algumas vezes, não um indício de acerto, mas de dificuldade na aquisição e desenvolvimento da escrita.

A escrita tende a se tomada como uma transcrição da oralidade e, neste sentido, grande importância também assume uma idéia de que para escrever bem é necessário saber falar bem, assim como ouvir bem para falar bem.

\section{Alterações ortográficas}

- Representações Múltiplas: quando um mesmo som pode ser escrito por várias letras ou uma mesma letra pode representar diferentes sons. Exemplos: o fonema /s/ pode ser representado por uma diversidade de letras como $s$, ss, ç, $c$; caçador, casador; sentido-centido.

-Apoio na oralidade: Palavras grafadas erroneamente em virtude de um apoio no modo de falar para decidir o modo de escrita, havendo uma discrepância entre os mesmos. Exemplos: trabalhar, trabaiar; dormir - dormi.

-Omissões de letras: quando palavras grafas de modo incompleto, em função da omissão de uma ou mais letras. Exemplos: sangue - sague; comprou-compou.

-Junção ou separação não convencional das palavras: problemas quando à segmentação resultam em palavras unidas entre si ou fracionadas em um menor número de sílabas do que deveriam ter. Exemplo: às vezes -asvezes; naquele - na quele.

-Confusão entre as terminaç̃es am e ao: palavras que terminam com am e que são grafadas com ao, e vice-versa. Exemplos: começaram - começarão; saíram - sairão.

-Generalização de regras: alterações decorrentes e formas de grafas palavras que parecem reveladoras do modo como as crianças generalizam certos procedimentos de escrita, porém aplicando-os a situações nem sempre apropriadas. Exemplo: fugiu - fugio; emagreceu - emagresel.

-Substituicão da grafia de fonemas surdos e sonoros: alterações de escrita dizendo respeito a determinadas substituições de grupos de letras que apresentam em comum o fato de representarem fonemas que se diferenciam pelo traço de sonoridade. Exemplos: pegando - peganto; perdido perdito.

-Acréscimos de letras: aumento ou acréscimo de letras na palavra escrita. Exemplos: machucar-manchucar; apareceu - papareceu. 
- Letras parecidas: palavras escritas erroneamente em razão do uso de letras incorretas, mas cuja grafia apresenta algumas semelhanças com a letra que deveria ser utilizada. Exemplos: tinha timha; caminho - caminlo.

-Inversão de letras: palavras apresentando letras em posição invertida no interior da sílaba, ou mesmo em posição distint daquela que deveria ocupar dentro da palavra. Exemplo: acabou arcodou; enxugar - enxugra.

-Outras: Alterações observadas em uma ou outra criança em particular, parecendo estar restrita à sua forma de escrever, isto é, seus erros ou enganos não eram partilhados de uma forma mais freqüente ou geral como as categorias anteriores.

\section{-Elaboração de texto e correção}




\section{(Apêndice J)}

\section{Planejamento de Trabalho}

\section{Assunto: SINAIS DE PONTUAÇÃO}

Existe um consenso entre os autores pesquisadores, de que existe, muitas dificuldades na transferência das convenções do discurso falado para o discurso escrito. Uma dessas dificuldades é o fato de que a linguagem falada dá possibilidade de assinalar uma grande quantidade de informações pragmáticas e semânticas por meio de prosódia, do contexto físico, dos gestos e dos recursos paralinguísticos.

Como no estilo escrito não há esses recursos, o escritor procura outros meios para delimitar suas características, sobretudo os sinais de pontuação.

Cardoso (1995) referiu que a tarefa do leitor é traduzir as suas idéias, que vêm à mente em relances, focos, flagrantes da linguagem, via de regra não relacionados entre si, $\mathrm{m}$ um todo formal e semanticamente organizado. Nesse processo de escrita, o recurso à entonação está presente, chegando até a acontecer de o escritor ler em voz alta a sua produção e, num processo de troca de papel, colocar-se no lugar do leitor, a fim de verificar a aceitabilidade do texto. Esse mesmo recurso permite ao escritor retomar e compreender o que leu e buscar formas de continuidade da escrita.

Kress (1982) enfatiza que a linguagem escrita possui estrutura e convenções próprias e que a pontuação pode ser definida como uma dessas, derivando mais da sintaxe da escrita do que da fala. Ou seja, a escolha para se colocar em um texto um ponto e vírgula em vez de uma vírgula é, mais frequentemente, uma escolha gramatical e textual, derivada de contingências da escrita, do que o reflexo de características entonacionais.

\section{Conclusão}

Assim, pode-se contatar que a aprendizagem da pontuação envolve muito mais que a transferência de habilidade da fala para a escrita: a aprendizagem de novas convenções, como por exemplo, o parágrafo, que é a grande estrutura textual que não existe na fala e que tem que ser aprendido desde o início da alfabetização.

\section{-Elaboração de texto}




\section{(Apêndice K)}

\section{Planejamento de Trabalho}

Assunto: Revisão, Construção de texto, Aplicação do Anexo III

1. Assuntos abordados:

- A Leitura e sua importância

-A concepção de texto

-A coesão

-A coerência

-Semântico e Estrutura sintática

-Léxico

-Erros ortográficos

-Uso adequado da de Pontuação

-Relação oralidade X escrita.

2. Elaborar um texto contendo adequadamente os assuntos abordados nas Oficinas de Aprimoramento da Comunicação escrita.

\section{Aplicação do Apêndice C}




\section{(Apêndice L)}

\section{Ditado e cópia}

\section{PALAVRAS}

-Bandeira

-Aquário

-Duplo

-Atravessar

-Assim

-Seguinte

-Chuva

-Enxergar

-Passeio

-Asa

-Exemplo

\section{FRASES}

1) O céu escureceu

2) A comida está salgada

3)A chuva derrubou o poste

4)O Brasil é campeão de futebol

5)Os brinquedos de pilha são bárbaros

6) A casa do João é roxa.

7) Segunda-feira tem prova de Português

8)Hoje em dia, temos que estudar para conseguir emprego

\section{Novas Conquistas}

O Metrô de São Paulo tem realizado sucessivas experiências práticas, a fim de testar concretamente um meio de transporte que visitaria uma forma de auxiliar a maior metrópole do Brasil.

A população foi instruída para a utilização eficiente dos bilhetes magnéticos. A partir de integração ônibus-metrô muitos puderam ser beneficiados. 